\title{
Integrated studies of a regional ozone pollution synthetically affected by subtropical high and typhoon system in the Yangtze River Delta region, China
}

\author{
Lei Shu, Min Xie, Tijian Wang, Da Gao, Pulong Chen, Yong Han, Shu Li, Bingliang Zhuang, and Mengmeng Li \\ School of Atmospheric Sciences, CMA-NJU Joint Laboratory for Climate Prediction Studies, Jiangsu Collaborative \\ Innovation Center for Climate Change, Nanjing University, Nanjing 210023, China
}

Correspondence to: Min Xie (minxie@nju.edu.cn) and Tijian Wang (tjwang@nju.edu.cn)

Received: 5 July 2016 - Published in Atmos. Chem. Phys. Discuss.: 1 August 2016

Revised: 19 November 2016 - Accepted: 9 December 2016 - Published: 23 December 2016

\begin{abstract}
Severe high ozone $\left(\mathrm{O}_{3}\right)$ episodes usually have close relations to synoptic systems. A regional continuous $\mathrm{O}_{3}$ pollution episode was detected over the Yangtze River Delta (YRD) region in China during 7-12 August 2013, in which the $\mathrm{O}_{3}$ concentrations in more than half of the cities exceeded the national air quality standard. The maximum hourly concentration of $\mathrm{O}_{3}$ reached $167.1 \mathrm{ppb}$. By means of the observational analysis and the numerical simulation, the characteristics and the essential impact factors of the typical regional $\mathrm{O}_{3}$ pollution are comprehensively investigated. The observational analysis shows that the atmospheric subsidence dominated by the western Pacific subtropical high plays a crucial role in the formation of high-level $\mathrm{O}_{3}$. The favorable weather conditions, such as extremely high temperature, low relative humidity and weak wind speed, caused by the abnormally strong subtropical high are responsible for the trapping and the chemical production of $\mathrm{O}_{3}$ in the boundary layer. In addition, when the YRD cities are at the front of Typhoon Utor, the periphery circulation of typhoon system can enhance the downward airflows and cause worse air quality. However, when the typhoon system weakens the subtropical high, the prevailing southeasterly surface wind leads to the mitigation of the $\mathrm{O}_{3}$ pollution. The integrated process rate (IPR) analysis incorporated in the Community Multi-scale Air Quality (CMAQ) model is applied to further illustrate the combined influence of subtropical high and typhoon system in this $\mathrm{O}_{3}$ episode. The results show that the vertical diffusion (VDIF) and the gas-phase chemistry (CHEM) are two major contributors to $\mathrm{O}_{3}$ formation. During the episode, the contributions of VDIF and CHEM to $\mathrm{O}_{3}$ maintain the high values over the YRD region. On 10-12 August, the cities close to the
\end{abstract}

sea are apparently affected by the typhoon system, with the contribution of VDIF increasing to $28.45 \mathrm{ppb} \mathrm{h}^{-1}$ in Shanghai and $19.76 \mathrm{ppbh}^{-1}$ in Hangzhou. In contrast, the cities far away from the sea can hardly be affected by the periphery circulation of typhoon system. When the typhoon system significantly weakens the subtropical high, the contribution values of all individual processes decrease to a low level in all YRD cities. These results provide an insight for the $\mathrm{O}_{3}$ pollution synthetically impacted by the western Pacific subtropical high and the tropical cyclone system.

\section{Introduction}

Ground-level ozone $\left(\mathrm{O}_{3}\right)$ is a secondary air pollutant generated by a series of complicated photochemical reactions involving nitrogen oxides $\left(\mathrm{NO}_{x}\right)$ and hydrocarbons $(\mathrm{HC})$ (Crutzen, 1973; Sillman, 1999; Jenkin et al., 2000; T. J. Wang et al., 2006; Xie et al., 2014, 2016b). Severe $\mathrm{O}_{3}$ pollution events usually occur in the presence of sunlight and under favorable meteorological conditions, with the abundance of $\mathrm{O}_{3}$ precursors ( $\mathrm{NO}_{x}$ and $\mathrm{HC}$ ) (T. J. Wang et al., 2006). This $\mathrm{O}_{3}$ pollution in troposphere can deteriorate the air quality and thereby cause adverse effects on human health and vegetation (Feng et al., 2003; Fann and Risley, 2013; Landry et al., 2013). Consequently, the formation mechanism and the integrated prevention of $\mathrm{O}_{3}$ pollution are of great concern in many megacities all over the world (Xie et al., 2016b).

Over the past decades, along with the rapid industrial and economic development, many areas in China have been suf- 
fering from high levels of $\mathrm{O}_{3}$ pollution. Especially in the most economically vibrant and densely populated areas, such as the Yangtze River Delta (YRD) region, the Pearl River Delta (PRD) region and the Beijing-Tianjin-Hebei (BTH) area, severe $\mathrm{O}_{3}$ pollution episodes have frequently occurred (Lam et al., 2005; T. J. Wang et al., 2006; An et al., 2007; Chan and Yao, 2008; Duan et al., 2008; Jiang et al., 2008; Zhang et al., 2008; Guo et al., 2009; Shao et al., 2009; Ma et al., 2012), and the background air pollutant concentrations have steadily increased (Chan and Yao, 2008; Zhang et al., 2008; Tang et al., 2009; T. Wang et al., 2009; Ma et al., 2012; Liu et al., 2013). Many studies on the $\mathrm{O}_{3}$ pollution, including satellite data analyses, field experiments and model simulations, have been carried out over China in order to investigate the temporal and spatial characteristics of surface photochemical pollution (Lu and Wang, 2006; H. X. Wang et al., 2006; Tu et al., 2007; Zhang et al., 2007, 2008; Geng et al., 2008; Tang et al., 2008, 2009; Chen et al., 2009; Han et al., 2011; Ding et al., 2013; Xie et al., 2016b), nonlinear photochemistry of $\mathrm{O}_{3}$ and its precursors (Lam et al., 2005; Ran et al., 2009; Liu et al., 2010; Li et al., 2011; Xie et al., 2014), interactions between $\mathrm{O}_{3}$ and aerosols (Lou et al., 2014; Shi et al., 2015), the effects of urbanization on $\mathrm{O}_{3}$ formation (Wang et al., 2007; X. M. Wang et al., 2009; Liao et al., 2015; Li et al., 2016; Xie et al., 2016a; Zhu et al., 2015) and other essential impact factors (Jiang et al., 2012; Li et al., 2012; Wei et al., 2012; Liu et al., 2013; Gao et al., 2016).

The YRD region is a highly developed area of urbanization and industrialization. With the accelerated economic development and remarkable increase in energy consumption, the photochemical smog with high levels of $\mathrm{O}_{3}$ concentration is becoming more and more prominent and frequent, tending to have significant regional pollution characteristics. (Chan and Yao, 2008; Ma et al., 2012; Li et al., 2012). Being located on the southeastern coast of China, YRD features a typical subtropical monsoon climate and is strongly affected by the western Pacific subtropical high in summer. Thus, high $\mathrm{O}_{3}$ concentrations are usually observed in late spring and summer by in situ monitoring (Ding et al., 2013; Xie et al., 2016b). Severe high $\mathrm{O}_{3}$ episodes usually have close relations to synoptic systems (Huang et al., 2005, 2006; T. J. Wang et al., 2006; Jiang et al., 2008; Cheng et al., 2014; Hung and Lo, 2015). Horizontal and vertical transport processes from upwind $\mathrm{O}_{3}$-rich air masses as well as poor atmospheric diffusion conditions can lead to the accumulation of surface $\mathrm{O}_{3}$ concentrations and aggravation of the photochemical pollution (T. J. Wang et al., 2006). In previous studies on high $\mathrm{O}_{3}$ pollution in the YRD region, some researchers have discussed this issue. For example, Jiang et al. (2012) investigated the spring $\mathrm{O}_{3}$ formation over East China and suggested that $\mathrm{O}_{3}$ concentrations over the $\mathrm{YRD}$ region were transported and diffused from surrounding areas. Li et al. (2012) presented quantitative analysis on atmospheric processes affecting $\mathrm{O}_{3}$ concentrations in the typical YRD cities during a summertime regional high $\mathrm{O}_{3}$ episode and found that the maxi- mum concentration of photochemical pollutants was usually related to the process of transportation. Gao et al. (2016) evaluated the $\mathrm{O}_{3}$ concentration during a frequent shifting wind period and revealed that vertical mixing played an important positive role in the formation of surface $\mathrm{O}_{3}$. However, these investigations only focused on the $\mathrm{O}_{3}$ formation mechanism for one megacity (such as Shanghai, Nanjing and Hangzhou) or just a single station. Up to now, studies on the process analysis of high ozone episodes over the YRD are quite limited (Li et al., 2012). So, more studies should pay attention to the typical weather systems and the exact formation mechanism of the regional $\mathrm{O}_{3}$ pollution in this region.

During 7-12 August 2013, there was a typical regional $\mathrm{O}_{3}$ pollution episode in the YRD region, which might be synthetically influenced by the western Pacific subtropical high and Typhoon Utor. To better understand the important factors impacting $\mathrm{O}_{3}$ formation from the regional scale, we investigated the exact roles of these two typical weather systems in this pollution episode by using observational analysis and numerical simulations. The observational analysis was performed to identify the temporal and spatial characteristics of the episode. The WRF/CMAQ modeling system, which consists of the Weather Research and Forecasting model (WRF) and the Community Multi-scale Air Quality (CMAQ) model, was used to reveal the exact formation mechanism. With the aid of the integrated process rate (IPR) analysis coupled in CMAQ, the qualitative and the quantitative analysis on the contributions of individual atmospheric processes were conducted as well. In this paper, brief descriptions of observational data and model configurations are shown in Sect. 2. A detailed observational analysis of air quality and meteorological conditions is given in Sect. 3. The evaluation of model performance and the formation mechanism of $\mathrm{O}_{3}$ explored by IPR technique are presented in Sect. 4. Finally, a summary of main findings is given in Sect. 5 .

\section{Methodology}

\subsection{Observed meteorological and chemical data}

The air quality observational data are used to identify the regional characteristics of the $\mathrm{O}_{3}$ episode in August 2013. Fifteen cities are selected as the representative research objects to better reflect the status of $\mathrm{O}_{3}$ pollution over the YRD region. The locations of these cities are shown in Fig. 1b, which contains Shanghai, eight cities in Jiangsu province (Changzhou, Nanjing, Nantong, Suzhou, Taizhou, Wuxi, Yangzhou and Zhenjiang) and six cities in Zhejiang province (Hangzhou, Huzhou, Jiaxing, Ningbo, Shaoxing and Zhoushan). The in situ monitoring data for the hourly concentrations of $\mathrm{O}_{3}, \mathrm{CO}, \mathrm{NO}_{2}, \mathrm{SO}_{2}, \mathrm{PM}_{2.5}$ and $\mathrm{PM}_{10}$ can be acquired from National Environmental Monitoring Center (NEMC). The quality assurance and quality control (QA/QC) procedures for monitoring strictly follow the na- 


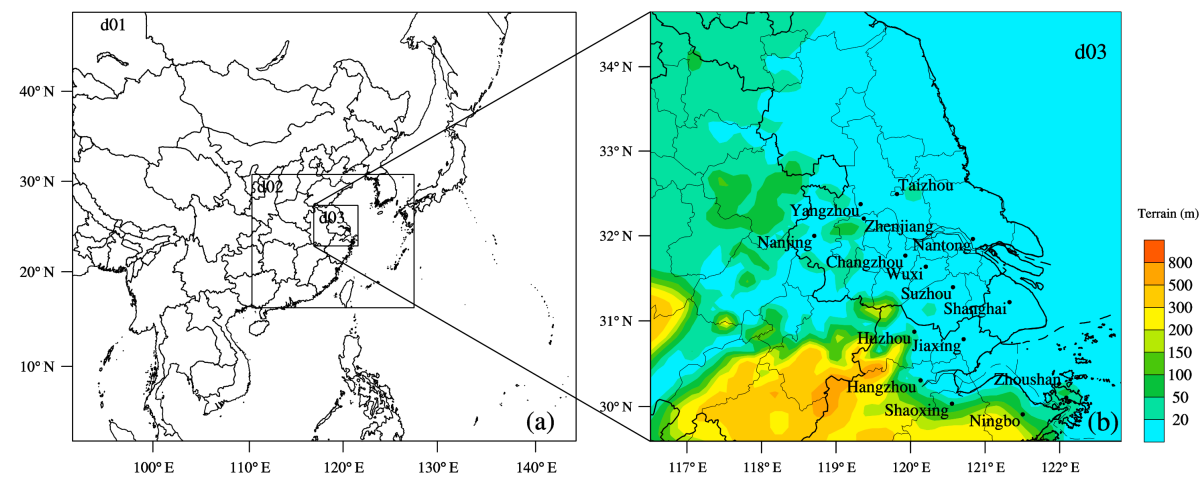

Figure 1. Domain settings, including (a) the three nested modeling domains and (b) the nested domain 3 (d03) with the terrain elevations and the locations of 15 main cities in the YRD region.

tional standards (State Environmental Protection Administration of China, 2006). The hourly pollutant concentration for a city is calculated as the average of the pollutant concentrations from several national monitoring sites in that city, which can better characterize the pollution level of the city. In order to identify invalid or lacking data, a checking procedure for these data is performed following the work of Chiqueto and Silva (2010). Finally, only less than $0.2 \%$ of the primary data are ignored in the calculation. Moreover, the observed data of total volatile organic carbons (TVOC) during 4-10 August at an urban site in Shanghai (SAES, $31.17^{\circ} \mathrm{N}$, $121.43^{\circ} \mathrm{E}$ ) are also used. They are provided by Shanghai Academy of Environmental Sciences. The sampling height is about $15 \mathrm{~m}$, and individual VOC species are continuously measured every $30 \mathrm{~min}$ by two online high performance gas chromatograph with flame ionization detector (GC-FID) systems (Chromato-sud airmoVOC C2-C6 no. 5250308 and airmoVOC C6-C12 no. 2260308, France). The details for measurement and QA/QC can refer to Wang et al. (2013).

The weather charts and the observed surface meteorological records are used to analyze the synoptic systems during the episode. The weather charts for East Asia are accessible from the Korea Meteorological Administration. The hourly meteorological data at the observation sites of $\mathrm{SH}\left(31.40^{\circ} \mathrm{N}\right.$, $\left.121.46^{\circ} \mathrm{E}\right)$ located in Shanghai, $\mathrm{HZ}\left(30.23^{\circ} \mathrm{N}, 120.16^{\circ} \mathrm{E}\right)$ in Hangzhou and $\mathrm{NJ}\left(32.00^{\circ} \mathrm{N}, 118.80^{\circ} \mathrm{E}\right)$ in Nanjing can be obtained from the University of Wyoming, where $2 \mathrm{~m}$ air temperature, $2 \mathrm{~m}$ relative humidity, $10 \mathrm{~m}$ wind speed and $10 \mathrm{~m}$ wind direction are available.

Meteorological and air quality observation data are also used to validate the reliability of simulations in this study. Comparisons of the modeling results with the observation data are performed in Shanghai, Nanjing and Hangzhou. Shanghai is the most populous city in China as well as a global financial and transportation center. Located to the northwest of Shanghai, Nanjing is the capital of the province of Jiangsu and the second largest commercial center in East China. Hangzhou is the capital of the province of Zhejiang and located to the southwest of Shanghai. These cities are the provincial capitals and the typical metropolis in the YRD region. They are highly urbanized and industrialized, and all suffer from severe $\mathrm{O}_{3}$ pollution.

\subsection{Model description and configurations}

In this study, WRF/CMAQ, which consists of WRF model version 3.4.1 and CMAQ model version 4.7.1, is applied to simulate the high $\mathrm{O}_{3}$ episode over the YRD region in August 2013. Developed at the National Center for Atmospheric Research (NCAR), WRF is a new generation of mesoscale weather forecast model and assimilation system. Numerous applications have proven that it shows a good performance in all kinds of weather forecasts and has broad application prospects in China (Jiang et al., 2008, 2012; X. M. Wang et al., 2009; Liu et al., 2013; Xie et al., 2014, 2016a; Liao et al., 2014, 2015; Li et al., 2016; Zhu et al., 2015). WRF provides offline meteorological fields as the input for the chemical transport model CMAQ. CMAQ is a third-generation regional air quality model developed by the Environmental Protection Agency of USA (USEPA). A set of up-todate compatible modules and control equations for the atmosphere is incorporated in the model, which can fully consider atmospheric complicated physical processes, chemical processes and the relative contribution of different species (Byun and Schere, 2006; Foley et al., 2010). CMAQ has been widely applied in China and proven to be a reliable tool in simulating air quality from city scale to mesoscale ( $\mathrm{Li}$ et al., 2012; Wei et al., 2012; Liu et al., 2013; Zhu et al., 2015).

The simulation run is conducted from 08:00 (local standard time, LST) on 2 August to 08:00 (LST) on $16 \mathrm{Au}-$ gust 2013, in which the first $48 \mathrm{~h}$ is taken as the spin-up time. Three one-way nested domains are used in WRF with a Lambert conformal map projection. The domain setting is shown in Fig. 1. The outermost domain (domain 1, d01) covers the most areas of East Asia and South Asia, with the horizontal grids of $88 \times 75$ and the grid spacing of $81 \mathrm{~km}$. The nested domain d02 covers the southeastern part of China, with the 
Table 1. The grid settings and the physical options for WRF in this study.

\begin{tabular}{ll}
\hline Items & Options \\
\hline Dimensions $(x, y)$ & $(88,75),(85,70),(70,64)$ \\
Grid spacing $(\mathrm{km})$ & $81,27,9$ \\
Microphysics & WRF Single-Moment 5-class scheme (Hong et al., 2004) \\
Longwave radiation & RRTM scheme (Mlawer et al., 1997) \\
Shortwave radiation & Goddard scheme (Kim and Wang, 2011) \\
Surface layer & Moni-Obukhov scheme (Monin and Obukhov, 1954) \\
Land-surface layer & Noah land-surface model (Chen and Dudhia, 2001) \\
Planetary boundary layer & YSU scheme (Hong et al., 2006) \\
Cumulus parameterization & Grell-Devenyi ensemble scheme (Grell and Devenyi, 2002) \\
\hline
\end{tabular}

horizontal grids of $85 \times 70$ and the grid spacing of $27 \mathrm{~km}$. The finest domain (domain 3, d03) covers the core areas of the YRD region, with the grid system of $70 \times 64$ and the resolution of $9 \mathrm{~km}$. For all domains, there are 23 vertical sigma layers from the surface to the top pressure of $100 \mathrm{hPa}$, with about 10 layers in the planetary boundary layer. The detailed configuration options for the dynamic parameterization in WRF are summarized in Table 1. Additionally, the SLAB scheme that does not consider urban canopy parameters is adopted to model the urban effect. In order to reflect the rapid urban expansion in the YRD region, the default United States Geological Survey (USGS) land-use archives are updated by adding the present urban land-use conditions from $500 \mathrm{~m}$ Moderate Resolution Imaging Spectroradiometer (MODIS) data, based on the work of Liao et al. (2014, 2015). The initial meteorological fields and boundary conditions are from $1^{\circ}$ resolution global reanalysis data provided by National Center for Environmental Prediction (NCEP). The boundary conditions are forced every $6 \mathrm{~h}$.

With respect to the air quality model, CMAQ uses the same vertical levels and the similar three nested domains as those adopted in the meteorological simulation, whereas the CMAQ domains are one grid smaller than the WRF domains. The Meteorology Chemistry Interface Processor (MCIP) is used to convert WRF outputs to the input meteorological files needed by CMAQ. The Carbon Bond 05 chemical mechanism (CB05) (Yarwood et al., 2005) is chosen for gas-phase chemistry (CHEM), and the fourth-generation CMAQ aerosol module (Byun and Schere, 2006) is adopted for aerosol chemistry. The initial and outmost boundary conditions are obtained from the Model for Ozone and Related Chemical Tracers version 4 (MOZART-4) (Emmons et al., 2010), while those for the two nested inner domains are extracted from the immediate concentration files of their parent domains. The anthropogenic emissions are mainly from the 2012 Multi-resolution Emission Inventory for China (MEIC) with $0.25^{\circ} \times 0.25^{\circ}$ resolution, which is re-projected for the grids of China in both domains. For the grids outside of China, the inventory developed for the Intercontinental Chemical Transport Experiment-Phase B (INTEX-B) by Zhang et al. (2009) is used. The natural $\mathrm{O}_{3}$ precursor emis- sions are calculated by the natural emission model developed by Xie et al. (2007, 2009, 2014), including NO from soil, VOCs from vegetation and $\mathrm{CH}_{4}$ from rice paddies and terrestrial plants. The biomass burning emissions are acquired from the work of Xie et al. (2014, 2016a).

\subsection{IPR analysis method}

The CMAQ modeling system contains process analysis module (PROCAN), which consists of the IPR analysis and the integrated reaction rate (IRR) analysis (Byun and Schere, 2006). IPR has the capability of calculating the hourly contributions of individual physical processes and the net effect of chemical reaction compared to the overall concentrations and thereby can determine the quantitative contribution of each process in a specific grid cell. The atmospheric processes considered in IPR include the horizontal advection (HADV), the vertical advection (ZADV), the horizontal diffusion (HDIF), the vertical diffusion (VDIF), the emissions (EMIS), the dry deposition (DDEP), the cloud processes with the aqueous chemistry (CLDS), the aerosol processes (AERO) and CHEM. IPR has been widely applied to investigate the regional photochemical pollution and has proven to be an effective tool to show the relative importance of every process and provide a fundamental interpretation (Gonçalves et al., 2009; Li et al., 2012; Liu et al., 2013; Zhu et al., 2015). In this paper, the period from 4 to 15 August is selected for the IPR analysis. With the aid of IPR, we assess the roles of the individual physical and chemical processes involved in $\mathrm{O}_{3}$ formation over the YRD region and further present those in the typical cities (Shanghai, Nanjing and Hangzhou).

\subsection{Evaluation method}

Comparisons of the modeling results in the finest domain (d03) with the hourly observation data are performed for meteorological factors and air pollutants in Shanghai, Hangzhou and Nanjing. The correlation coefficient $(R)$, the normalized mean bias (NMB) and the root-mean-square error (RMSE) are used to evaluate the model performance. These statistic 


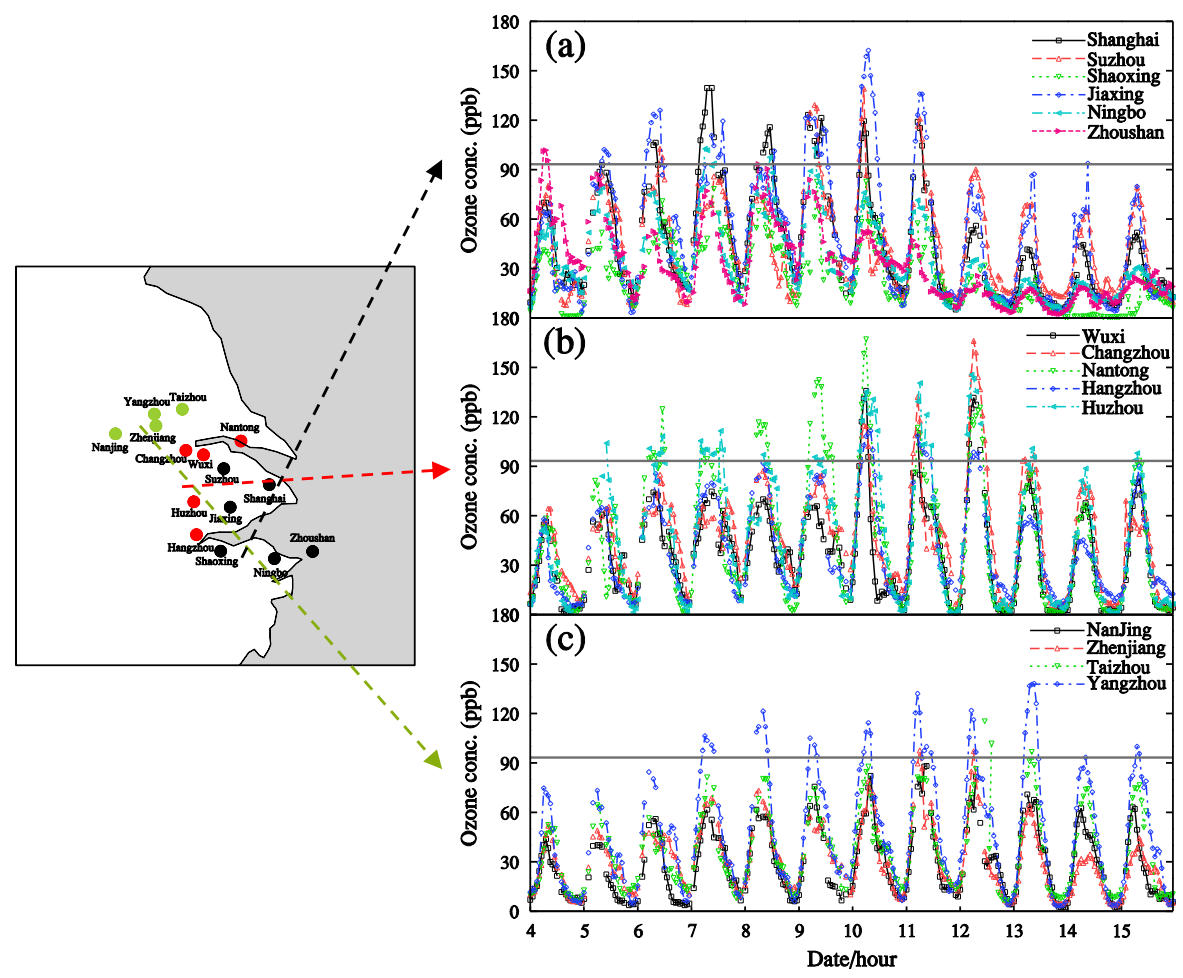

Figure 2. The time series of the observed $\mathrm{O}_{3}$ concentrations in 15 typical cities from 4 to 15 August 2013 over the YRD region, which can be divided into three areas: (a) the Southeast Coast Region (SCR), including Shanghai, Suzhou, Shaoxing, Jiaxing, Ningbo and Zhoushan; (b) the Central Inland Region (CIR), including Wuxi, Changzhou, Nantong, Hangzhou and Huzhou; (c) the Northwest Inland Region (NIR), including Nanjing, Zhenjiang, Taizhou and Yangzhou. The gray solid lines in (a), (b) and (c) represent the national standard for the hourly $\mathrm{O}_{3}$ concentration, which is $200 \mu \mathrm{g} \mathrm{m}^{-3}$.

values are calculated as follows:

$$
\begin{gathered}
R=\frac{\sum_{i=1}^{N}\left(S_{i}-\bar{S}\right)\left(O_{i}-\bar{O}\right)}{\sqrt{\sum_{i=1}^{N}\left(S_{i}-\bar{S}\right)^{2}} \sqrt{\sum_{i=1}^{N}\left(O_{i}-\bar{O}\right)}}, \\
\mathrm{NMB}=\frac{\sum_{i=1}^{N}\left(S_{i}-O_{i}\right)}{\sum_{i=1}^{N} O_{i}} \times 100 \%,
\end{gathered}
$$

where $S_{i}$ and $O_{i}$ represent the simulated and the observed value, respectively. $N$ means the total number of valid data. Generally, the model performance is acceptable if the values of NMB and RMSE are close to 0 and that of $R$ is close to 1 .

\section{Characteristics of the continuous ozone episode}

\subsection{Basic characteristic of the regional ozone episode in August 2013}

Figure 2 shows the temporal variation of the hourly $\mathrm{O}_{3}$ concentrations observed in 15 typical cities over the YRD region from 00:00 (universal time coordinated, UTC) $4 \mathrm{Au}-$ gust to 23:00 (UTC) 15 August in 2013. Obviously, from 7 to 12 August, high $\mathrm{O}_{3}$ concentrations over $93.5 \mathrm{ppb}$ (approximately equal to the hourly national air quality standard of $200 \mu \mathrm{g} \mathrm{m}^{-3}$ ) have been frequently recorded in 13 cities, which means $\mathrm{O}_{3}$ concentrations in most cities over the YRD region exceed the national air quality standard. So, this high $\mathrm{O}_{3}$ pollution episode is a typical regional $\mathrm{O}_{3}$ pollution episode that can affect the people and the ecosystem in a large area. In general, for each city, there is a remarkable continuous growth in $\mathrm{O}_{3}$ concentrations before the $\mathrm{O}_{3}$ episode, followed by the lasting heavy $\mathrm{O}_{3}$ pollution period. Though the $\mathrm{O}_{3}$ concentrations in Shaoxing and Nanjing meet the national $\mathrm{O}_{3}$ standard, their time series still show the similar tendency to those of the other cities in the same region. The excessive level of $\mathrm{O}_{3}$ occurring in Huzhou, Jiaxing, Nantong, Yangzhou and Shanghai lasts for more than 6 consec- 
Table 2. The maximum and average concentrations of $\mathrm{O}_{3}$ and $\mathrm{NO}_{2}$ observed in 15 cities during 7-12 August 2013 (ppb).

\begin{tabular}{llrr|rr}
\hline \multirow{2}{*}{ Sites } & & \multicolumn{2}{c}{$\mathrm{O}_{3}$} & \multicolumn{2}{c}{$\mathrm{NO}_{2}$} \\
\cline { 3 - 5 } & & Max & Mean & Max & Mean \\
\hline \multirow{2}{*}{ Southeast Coast Region (CSR) } & Shanghai & 139.5 & 55.1 & 35.1 & 15.6 \\
& Suzhou & 139.1 & 50.9 & 50.6 & 19.7 \\
& Jiaxing & 162.4 & 61.1 & 52.1 & 17.1 \\
& Ningbo & 113.4 & 41.9 & 31.2 & 12.4 \\
& Shaoxing & 82.6 & 31.9 & 27.8 & 12.7 \\
& Zhoushan & 93.6 & 35.5 & 27.3 & 7.8 \\
\hline \multirow{2}{*}{ Central Inland Region (CIR) } & Hangzhou & 111.5 & 48.6 & 30.2 & 16.7 \\
& Huzhou & 145.6 & 57.2 & 43.8 & 20.8 \\
& Wuxi & 135.8 & 43.2 & 39.9 & 18.8 \\
& Changzhou & 166.1 & 55.7 & 58.4 & 24.5 \\
& Nantong & 167.1 & 56.0 & 48.2 & 20.9 \\
\hline Northwest Inland Region (NIR) & Nanjing & 88.2 & 34.1 & 41.4 & 21.9 \\
& Yangzhou & 132.1 & 54.1 & 36.0 & 17.1 \\
& Zhenjiang & 97.5 & 37.7 & 38.5 & 20.1 \\
& Taizhou & 115.3 & 40.5 & 18.5 & 7.7 \\
\hline
\end{tabular}

utive days, reflecting the regional continuous characteristics of this $\mathrm{O}_{3}$ pollution episode.

According to the temporal variation characteristics of $\mathrm{O}_{3}$ illustrated in Fig. 2, the abovementioned 15 typical YRD cities can be classified into three categories: (1) the cities in the Southeast Coastal Region (SCR), including Shanghai, Suzhou, Jiaxing, Ningbo, Shaoxing and Zhoushan; (2) the cities in the Central Inland Region (CIR), including Hangzhou, Huzhou, Wuxi, Changzhou and Nantong; and (3) the cities in the Northwest Inland Region (NIR), including Nanjing, Yangzhou, Zhenjiang and Taizhou. The classification is primarily on basis of the observational facts that the maximum $\mathrm{O}_{3}$ concentrations occur on 10-11, 12 and 13 August and begin to synchronously decrease on 12, 13 and 14 August in SCR, CIR and NIR, respectively. As shown in Fig. 2, in the SCR, Zhoushan firstly exceeds the national $\mathrm{O}_{3}$ standard on 4 August, followed by Jiaxing, Shanghai, Suzhou and Ningbo. The peak hourly $\mathrm{O}_{3}$ concentration of SCR occurs in Jiaxing on 10 August, with the value up to $162.4 \mathrm{ppb}$. In the CIR, Huzhou is the first city exceeding the national $\mathrm{O}_{3}$ standard, followed by the order of Nantong, Changzhou, Wuxi and Hangzhou. The high-level $\mathrm{O}_{3}$ pollution in Huzhou lasts from 5 to 13 August. In Nantong and Changzhou, the maximum hourly $\mathrm{O}_{3}$ concentration reaches 167.1 ppb on 10 August and $166.1 \mathrm{ppb}$ on 12 August, respectively. As for the NIR, Yangzhou, Zhenjiang and Taizhou successively exceed the national $\mathrm{O}_{3}$ standard. It is also noteworthy that the date when $\mathrm{O}_{3}$ concentration exceeds the national air quality standard in coastal region is ahead of that in inland regions, as is the date of $\mathrm{O}_{3}$ decrease. The different start time of $\mathrm{O}_{3}$ decreasing in different regions might be related to the strong southeast wind in accordance with the movement of Typhoon Utor, which is discussed in Sect. 3.2 in detail.

Table 2 presents the maximum and the average concentrations of $\mathrm{O}_{3}$ and $\mathrm{NO}_{2}$ in 15 YRD cities during 7-12 August 2013. It illustrates that the mean concentrations of $\mathrm{NO}_{2}$ in different YRD cities range from 7.7 to $24.5 \mathrm{ppb}$ during the $\mathrm{O}_{3}$ episode, indicating the heterogeneity of the spatial distribution of $\mathrm{O}_{3}$ precursor emissions. For $\mathrm{O}_{3}$, the highest hourly concentration (167.1 ppb) occurs in Nantong, followed by $166.1 \mathrm{ppb}$ in Changzhou and $162.4 \mathrm{ppb}$ in Jiaxing. These values are all nearly 2 times the national air quality standard. It seems that $\mathrm{O}_{3}$ concentrations are higher in the cities around Shanghai, where the concentrations of $\mathrm{O}_{3}$ precursors are more adequate as well. High concentrations of $\mathrm{O}_{3}$ and its precursors imply that there may be stronger photochemical reactions.

Figure 3 demonstrates the hourly variations of the observed $\mathrm{NO}_{2}$ concentrations in Shanghai, Nanjing and Hangzhou from 4 to 15 August 2013 and the time series of TVOC observed at SAES in Shanghai from 4 to $10 \mathrm{Au}-$ gust 2013. Obviously, there are two peaks in the diurnal cycles of $\mathrm{NO}_{2}$ and VOC at all sites, which should be related to the rush hours in cities. The photolysis of $\mathrm{NO}_{2}$ dominates $\mathrm{O}_{3}-\mathrm{VOC}-\mathrm{NO}_{x}$ chemistry after 08:00 and thereby makes the concentrations of precursors $\left(\mathrm{NO}_{2}\right.$ and VOC) begin to decrease. Thus, the related reactions form $\mathrm{O}_{3}$ and increase its concentration until about 14:00. These diurnal variations of $\mathrm{O}_{3}$ and its precursors follow the typical patterns in the polluted areas and reflect the close relationships between $\mathrm{O}_{3}$, VOC and $\mathrm{NO}_{x}$ (Wang et al., 2013; Xie et al., 2016b). Moreover, the daily variations of $\mathrm{NO}_{2}$ and VOC show good agreement with those of $\mathrm{O}_{3}$. For VOC, the concentration in Shanghai largely increases since 6 August, which corresponds well 


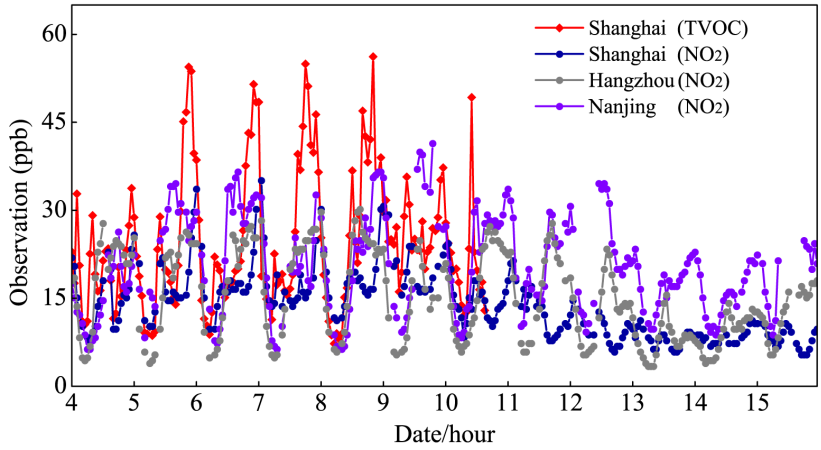

Figure 3. Temporal variations of the observed $\mathrm{NO}_{2}$ concentrations at Shanghai, Nanjing and Hangzhou stations from 4 to 15 August 2013 and the observed TVOC concentration at SAES $\left(31.17^{\circ} \mathrm{N}\right.$, $121.43^{\circ} \mathrm{E}$ ) in Shanghai from 4 to 10 August 2013.

with the over-standard $\mathrm{O}_{3}$ concentrations since then (Fig. 2). For $\mathrm{NO}_{2}$, the higher values occur from 6 to 11 August in all cities, but the concentrations start to decrease on 12, 13 and 14 August in Shanghai, Hangzhou and Nanjing, respectively. It seems that the changes of $\mathrm{O}_{3}$ precursors $\left(\mathrm{NO}_{2}\right.$ and VOC) are also affected by the movement of Typhoon Utor.

\subsection{Meteorological condition and its effect}

Favorable weather conditions have large impacts on the formation of severe $\mathrm{O}_{3}$ pollution (Huang et al., 2005, 2006; T. J. Wang et al., 2006; Jiang et al., 2008; Cheng et al., 2014; Hung and Lo, 2015). High-level $\mathrm{O}_{3}$ episodes often take place in hot seasons, when the meteorological conditions with high temperature and strong solar radiation are beneficial to the photochemical reactions of $\mathrm{O}_{3}$ (Lam et al., 2005). Figure 4 shows the variations of the surface meteorological parameters that are related to this photochemical pollution episode during 4-15 August, including $2 \mathrm{~m}$ air temperature, $2 \mathrm{~m}$ relative humidity, $10 \mathrm{~m}$ wind speed and $10 \mathrm{~m}$ wind direction at the meteorological sites in Shanghai (SH) of SCR, Hangzhou (HZ) of CIR and Nanjing (NJ) of NIR.

As shown in Fig. 4a, the hot weather at $\mathrm{SH}, \mathrm{HZ}$ and NJ exists for nearly a week from 7 to 12 August, with the hourly maximum temperature reaching the value over $40^{\circ} \mathrm{C}$. Meanwhile, the variations of $2 \mathrm{~m}$ relative humidity show the negative correlation with those of $2 \mathrm{~m}$ air temperature. The minimum $2 \mathrm{~m}$ relative humidity at $\mathrm{SH}$ and $\mathrm{HZ}$ occur on 9 and 10 August respectively, with the value below $75 \%$. These minimum values are also lower than the values before and after the $\mathrm{O}_{3}$ episode, suggesting that high-level $\mathrm{O}_{3}$ episodes usually occur under the weather conditions with high temperature and low humidity. The value of $2 \mathrm{~m}$ relative humidity at $\mathrm{NJ}$ is relatively higher than those at $\mathrm{SH}$ and $\mathrm{HZ}$ and remains more stable. These extremely hot and dry weather conditions at $\mathrm{SH}, \mathrm{HZ}$ and $\mathrm{NJ}$ are successively relieved on 12, 13 and 15 August, which coincides well with the reduction of sur- face $\mathrm{O}_{3}$ concentrations in Shanghai, Hangzhou and Nanjing (Fig. 2). With respect to the observed surface wind (Fig. 4b), the $10 \mathrm{~m}$ wind speed at $\mathrm{SH}$ and $\mathrm{HZ}$ is comparatively lower during the period of the $\mathrm{O}_{3}$ episode, while it is suddenly intensified after 12 August. Meanwhile, the wind direction is fluctuating from 7 to 12 August, while it maintains southeasterly wind after 12 August as well. The growth of wind speed is more distinct at $\mathrm{SH}$, with the maximum value of approximately $10 \mathrm{~m} \mathrm{~s}^{-1}$. The wind speed at $\mathrm{NJ}$ has an obviously diurnal variation from 4 to 8 August, and the minimum value occurs on 10 August.

Figure 5 displays the weather charts for the $500 \mathrm{hPa}$ layer over East Asia at 00:00 (UTC) on 6, 8, 10 and 12 August 2013, which can illustrate the main synoptic patterns causing the $\mathrm{O}_{3}$ pollution. Obviously, during the period of the selected $\mathrm{O}_{3}$ episode, the whole YRD region is under the control of the strong western Pacific subtropical high, which is stronger and extends much farther west than normal. The anomaly of the subtropical high might be the direct and leading cause of the abnormally high temperature shown in Fig. 4a (Peng et al., 2014). The intensity of the subtropical high is usually characterized by the area index, defined as the total number of grid points that have geopotential heights of 588 decameters or greater in the region of $110-180^{\circ} \mathrm{E}$ and northward of $10^{\circ} \mathrm{N}$. As shown in Fig. 5, the 5880-m area covers most of southeast China, and the high pressure center (5920-m area) is located in the southeastern coastal areas as well as the surrounding sea areas, which means the subtropical high is very intensive. This high pressure strengthens and remains over the YRD region for several days (from 6 to 12 August), implying that the air subsides to the ground. The downward air acts as a dome capping the atmosphere and helps to trap heat as well as air pollutants at the surface. Without the lift of air, there is little convection and therefore little cumulus clouds or rains. The end result is a continual accumulating of solar radiation and heat on the ground, which may greatly enhance the photochemical reactions between the abundant built-up air pollutants.

The other weather system worthy of note is Typhoon Utor (shown in Fig. 5c and d). Typhoon Utor is one of the strongest typhoons in the 2013 Pacific typhoon season. It is formed early on 8 August, develops into a tropical storm on $9 \mathrm{Au}-$ gust, undergoes an explosive intensification within a half of day and achieves typhoon status early on 10 August. After landing in Luzon of the Philippines on late 11 August, it reemerges in the South China Sea on 12 August. Typhoon Utor hits the land of Guangdong Province in China on 14 August and thereby is finally weakened into a tropical storm. In the end, it is ultimately dissipated on 18 August. It was reported that ozone episodes during the hot season are usually associated with the passage of tropical cyclones close to the territory (Huang et al., 2005; T. J. Wang et al., 2006; Jiang et al., 2008; Cheng et al., 2014; Hung and Lo, 2015). When a site is at the front of moving typhoon system, it can be controlled by the downward airflow induced by the typhoons' 


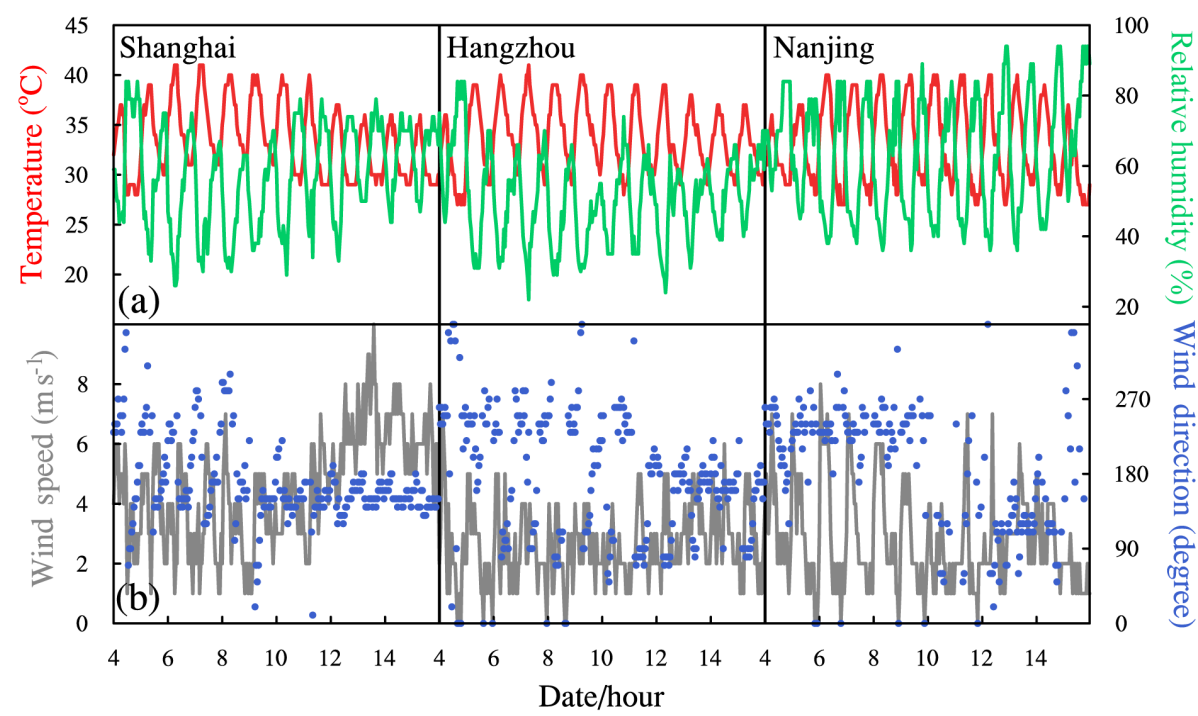

Figure 4. Temporal variations of the main meteorological parameters at Shanghai, Hangzhou and Nanjing meteorological stations during 4-15 August 2013, including (a) $2 \mathrm{~m}$ air temperature (the red solid line) and $2 \mathrm{~m}$ relative humidity (the green solid line) and (b) $10 \mathrm{~m}$ wind speed (the gray solid line) and $10 \mathrm{~m}$ wind direction (the blue scatter points).
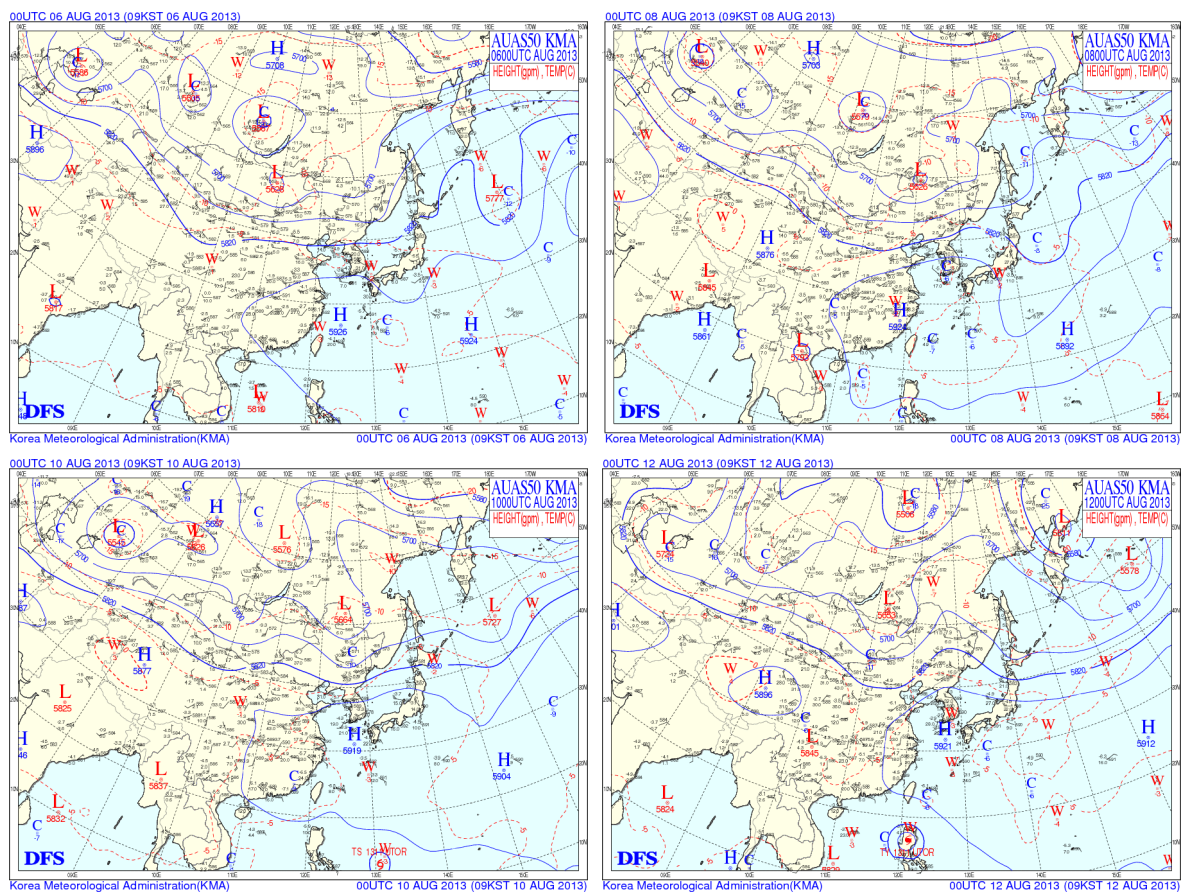

Figure 5. Weather charts at the $500 \mathrm{hPa}$ layer over the East Asia at 00:00 (UTC) on (a) 6 August, (b) 8 August, (c) 10 August and (d) 12 August 2013 (from Korea Meteorological Administration).

peripheral circulation. So, the typhoon system can cause the local weather around the site with high temperature, low humidity, strong solar radiation and small wind for a short time, before it is close enough to bring winds and rains. All these changes of meteorological conditions can help to form the severe continuous $\mathrm{O}_{3}$ pollution (Jiang et al., 2008). In this $\mathrm{O}_{3}$ episode, the YRD region may be influenced by the pe- ripheral circulation of Typhoon Utor as well. Especially on 10-11 August, the downward airflow in the troposphere is significantly strengthened (shown in Fig. 7), which may enhance the buildup of heat and air pollutants and thereby result in worse air quality, shown in Fig. 2.

Moreover, with the approaching of Typhoon Utor from 12 to 14 August, the near-surface breeze over the YRD region 
Table 3. Comparisons between the simulations and the observations at Shanghai, Nanjing and Hangzhou stations during 4-15 August 2013.

\begin{tabular}{|c|c|c|c|c|c|c|}
\hline \multirow[t]{2}{*}{ Site $^{\mathrm{a}}$} & \multirow[t]{2}{*}{ Vars ${ }^{b}$} & \multicolumn{2}{|c|}{ Mean } & \multirow[t]{2}{*}{$R^{\mathrm{e}}$} & \multirow[t]{2}{*}{$\mathrm{NMB}^{\mathrm{f}}$} & \multirow[t]{2}{*}{ RMSE $^{\mathrm{g}}$} \\
\hline & & $\mathrm{OBS}^{\mathrm{c}}$ & SIM $^{\mathrm{d}}$ & & & \\
\hline \multirow[t]{6}{*}{ SH } & $T_{2}\left({ }^{\circ} \mathrm{C}\right)$ & 33.27 & 31.38 & 0.91 & $-5.68 \%$ & 4.15 \\
\hline & $\mathrm{RH}_{2}(\%)$ & 57.91 & 65.23 & 0.85 & $12.64 \%$ & 19.3 \\
\hline & $\mathrm{Wspd}_{10}\left(\mathrm{~m} \mathrm{~s}^{-1}\right)$ & 4.59 & 4.66 & 0.77 & $1.53 \%$ & 2.18 \\
\hline & $\operatorname{Wdir}_{10}\left(^{\circ}\right)$ & 176.34 & 182.57 & 0.63 & $3.53 \%$ & 41.44 \\
\hline & $\mathrm{O}_{3}(\mathrm{ppb})$ & 87.77 & 82.5 & 0.81 & $-6.00 \%$ & 38.79 \\
\hline & $\mathrm{NO}_{2}(\mathrm{ppb})$ & 29.01 & 38.25 & 0.54 & $31.85 \%$ & 28.95 \\
\hline \multirow[t]{6}{*}{ NJ } & $T_{2}\left({ }^{\circ} \mathrm{C}\right)$ & 32.95 & 30.98 & 0.84 & $-5.98 \%$ & 2.91 \\
\hline & $\mathrm{RH}_{2}(\%)$ & 63.28 & 66.14 & 0.83 & $4.52 \%$ & 9.41 \\
\hline & $\mathrm{Wspd}_{10}\left(\mathrm{~m} \mathrm{~s}^{-1}\right)$ & 3.21 & 3.4 & 0.74 & $5.92 \%$ & 2.41 \\
\hline & $W \operatorname{dir}_{10}\left(^{\circ}\right)$ & 197.68 & 194.58 & 0.57 & $-1.57 \%$ & 71.19 \\
\hline & $\mathrm{O}_{3}(\mathrm{ppb})$ & 69.7 & 78.15 & 0.81 & $12.12 \%$ & 36.8 \\
\hline & $\mathrm{NO}_{2}(\mathrm{ppb})$ & 41.44 & 40.09 & 0.61 & $-3.26 \%$ & 22.4 \\
\hline \multirow[t]{6}{*}{$\mathrm{HZ}$} & $T_{2}\left({ }^{\circ} \mathrm{C}\right)$ & 33.25 & 31.08 & 0.8 & $-6.53 \%$ & 3.09 \\
\hline & $\mathrm{RH}_{2}(\%)$ & 52.76 & 61.39 & 0.78 & $16.36 \%$ & 13.96 \\
\hline & $\mathrm{Wspd}_{10}\left(\mathrm{~m} \mathrm{~s}^{-1}\right)$ & 3.04 & 3.32 & 0.75 & $9.21 \%$ & 2.39 \\
\hline & $\mathrm{Wdir}_{10}\left(^{\circ}\right)$ & 186.45 & 186.2 & 0.58 & $-0.13 \%$ & 69.44 \\
\hline & $\mathrm{O}_{3}(\mathrm{ppb})$ & 76.57 & 84.51 & 0.83 & $10.37 \%$ & 33.95 \\
\hline & $\mathrm{NO}_{2}(\mathrm{ppb})$ & 31.06 & 27.21 & 0.66 & $-12.40 \%$ & 16.86 \\
\hline
\end{tabular}

a Site indicates the city where the observation sites locate, including Shanghai (SH), Nanjing (NJ) and Hangzhou (HZ). ${ }^{\mathrm{b}}$ Vars indicates the variables under validation, including $2 \mathrm{~m}$ air temperature $\left(T_{2}\right), 2 \mathrm{~m}$ relative humidity $\left(\mathrm{RH}_{2}\right), 10 \mathrm{~m}$ wind speed $\left(\mathrm{Wspd}_{10}\right), 10 \mathrm{~m}$ wind direction $\left(\mathrm{Wdir}_{10}\right)$, ozone $\left(\mathrm{O}_{3}\right)$ and nitrogen dioxide $\left(\mathrm{NO}_{2}\right)$. The words between the parentheses behind variables indicate the unit. ${ }^{\mathrm{c}}$ OBS indicates the observation data. ${ }^{\mathrm{d}}$ SIM indicates the simulation results from WRF/CMAQ. ${ }^{\mathrm{e}} R$ indicates the correlation coefficients, with statistically significant at $95 \%$ confident level. ${ }^{f} \mathrm{NMB}$ indicates the normalized mean bias. ${ }^{\mathrm{g}}$ RMSE indicates the root-mean-square error.

gradually becomes the prevailing southeasterly or southerly wind (Fig. 5d), with the highest wind speed up to $6-10 \mathrm{~m} \mathrm{~s}^{-1}$ in Shanghai (Fig. 4). The strengthened wind can bring the clean marine air from ocean to inland and thereby effectively mitigate the $\mathrm{O}_{3}$ pollution. Meantime, Typhoon Utor also gradually affects the position and strength of the western Pacific subtropical high. As the typhoon continuously approaches and finally lands on Guangdong, the high pressure system is forced to retreat easterly and move northwards. When the high pressure center completely moves to the oceans, the YRD region is totally under the control of the typhoon system. In the end, the hot weather is relieved and the $\mathrm{O}_{3}$ pollution is mitigated. The coastal cities in CSR are closer to the typhoon system, so they are firstly influenced during this period. Thus, the wind at SH in CSR firstly changes, followed by HZ in CIR and NJ in NIR. In the same way, $2 \mathrm{~m}$ air temperature and $\mathrm{O}_{3}$ concentrations also successively decrease from southeast (SH in CSR) to northwest (NJ in NIR) owing to the scavenging effect.

\section{Modeling results and discussions}

\subsection{Evaluation of model performance}

To evaluate the simulation performance, the hourly modeling results during the period of 4-15 August 2013 are compared with the observation records. Table 3 presents the performance statistics, including the values of $R$, the NMB and the RMSE, which are all calculated for $2 \mathrm{~m}$ air temperature $\left(T_{2}\right)$, $2 \mathrm{~m}$ relative humidity $\left(\mathrm{RH}_{2}\right), 10 \mathrm{~m}$ wind speed $\left(\mathrm{Wspd}_{10}\right)$, $10 \mathrm{~m}$ wind direction $\left(\mathrm{Wdir}_{10}\right)$, surface $\mathrm{O}_{3}$ concentrations and surface $\mathrm{NO}_{2}$ concentrations in $\mathrm{SH}, \mathrm{NJ}$ and $\mathrm{HZ}$.

As indicated in Table 3, the simulated results of surface air temperature and relative humidity from WRF show good agreement with the observations. The highest correlation coefficient of $T_{2}$ is found to be 0.91 at $\mathrm{SH}$, followed by 0.84 at $\mathrm{NJ}$ and 0.80 at $\mathrm{HZ}$ (statistically significant at $95 \%$ confident level). The corresponding correlation coefficients for $\mathrm{RH}_{2}$ are $0.85,0.83$ and 0.78 , respectively. The values of RMSE for $\mathrm{T}_{2}$ at $\mathrm{SH}, \mathrm{NJ}$ and $\mathrm{HZ}$ are $4.15,2.91$ and $3.09^{\circ} \mathrm{C}$ and those for $\mathrm{RH}_{2}$ are 19.3, 9.41 and $13.96 \%$, respectively. Our simulation underestimates $T_{2}$ and overestimates $\mathrm{RH}_{2}$ to some certain extent, with the values of NMB for $T_{2}$ at $\mathrm{SH}$, $\mathrm{NJ}$ and $\mathrm{HZ}$ being $-5.68,-5.98$ and $-6.53 \%$ and those for $\mathrm{RH}_{2}$ being $12.64,4.52$ and $16.36 \%$. These biases might be 
attributed to the uncertainty caused by the SLAB scheme, which can underestimate temperature in summer (Liao et al., 2014). However, according to the relevant studies ( $\mathrm{Li}$ et al., 2012; Liao et al., 2015; Xie et al., 2016a), this level of overor underestimation is still acceptable. The wind components are closely related to the transport processes. As shown in Table 3, our modeling results of wind speed and direction basically reflect the characteristics of wind fields. For $\mathrm{Wspd}_{10}$, $R$ is 0.77 at $\mathrm{SH}, 0.74$ at $\mathrm{NJ}$ and 0.75 at $\mathrm{HZ}$. Though the values of $\operatorname{NMB}(1.53,5.92$ and $9.21 \%)$ and $\operatorname{RMSE}(2.18,2.41$ and 2.39) display that the simulated wind speeds are a little overestimated, the biases are still reasonable and acceptable. For $\mathrm{Wdir}_{10}$, the simulated values also fit the observation records well, with the $R$ values of 0.63 at $\mathrm{SH}, 0.57$ at $\mathrm{NJ}$ and 0.58 at HZ. Comparing the mean values from SIM and OBS, we can find that WRF model generally simulates the prevailing wind direction during this period. In summary, the abovementioned performance statistics numbers illustrate that the WRF simulation can reflect the major characteristics of meteorological conditions of this $\mathrm{O}_{3}$ episode, and the meteorological outputs can be used in the pollutant concentration simulation.

Figure 6 shows the comparisons between the modeling results from CMAQ and the observed hourly concentrations of $\mathrm{O}_{3}$ in Shanghai, Nanjing and Hangzhou during 4-15 August 2013. Obviously, the observations and the simulated results present reasonable agreement at each site, with the correlation coefficients of 0.81 to 0.83 , NMB of -6 to $12.12 \%$ and RMSE of 33.95 to $38.79 \mathrm{ppb}$. Moreover, the simulation also reproduces the diurnal variation of $\mathrm{O}_{3}$, which shows that the concentration reaches its maximum at around noontime and gradually decreases to its minimum after midnight. With respect to the $\mathrm{O}_{3}$ precursor, comparisons of $\mathrm{NO}_{2}$ concentrations between simulation results and observations show that the correlation coefficient at each city is about 0.6 (given in Table 3), which further proves that the process of $\mathrm{O}_{3}$ formation is captured reasonable well over the YRD region and throughout the episode. However, CMAQ overestimates $\mathrm{NO}_{2}$ and underestimates $\mathrm{O}_{3}$ in Shanghai, while it underestimates $\mathrm{NO}_{2}$ and overestimates $\mathrm{O}_{3}$ in Nanjing and Hangzhou. These biases of $\mathrm{O}_{3}$ and $\mathrm{NO}_{2}$ should mainly be attributed to the uncertainties in emissions of $\mathrm{O}_{3}$ precursors $\left(\mathrm{NO}_{x}\right.$ and VOCs) (Li et al., 2012; Liao et al., 2015; Xie et al., 2016). Because of the VOC-sensitive $\mathrm{O}_{3}$ chemistry in the daytime and $\mathrm{NO}_{x}$ titration at night in the YRD region (Xie et al., 2014), higher estimation of $\mathrm{NO}_{x}$ emission in Shanghai may lead to higher $\mathrm{NO}_{2}$ and lower $\mathrm{O}_{3}$ predictions, while lower $\mathrm{NO}_{x}$ estimations in Nanjing and Hangzhou may result in lower $\mathrm{NO}_{2}$ and higher $\mathrm{O}_{3}$ modeling results. The undervalued $\mathrm{NO}_{2}$ and overvalued $\mathrm{O}_{3}$ in Nanjing and Hangzhou can also be related to the overestimations in $\mathrm{WS}_{10}$ and the negative biases in $T_{2}$. Moreover, the uncertainties in nonlinear chemical reactions coupled in CMAQ may also have important effects on model predictions. For example, the modeling results cannot catch the low $\mathrm{O}_{3}$ values observed at night in Nanjing and

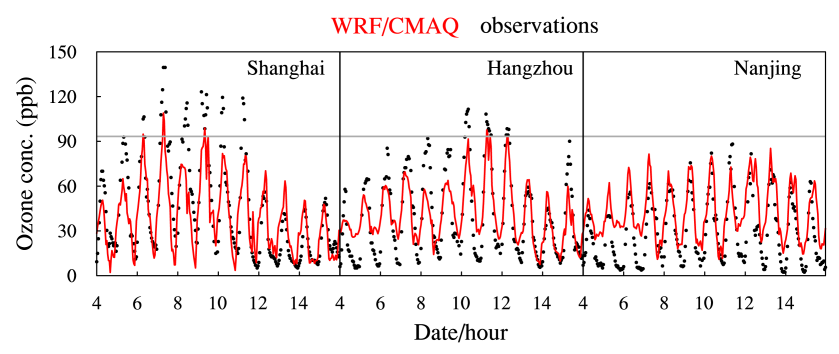

Figure 6. Hourly variations of the observed and the simulated $\mathrm{O}_{3}$ concentrations in Shanghai, Nanjing and Hangzhou during 4 to 15 August 2013. The red solid lines show the modeling results, the black dot lines give the observations, and the solid gray lines represent the national standard for the hourly $\mathrm{O}_{3}$ concentration, which is $200 \mu \mathrm{g} \mathrm{m}^{-3}$.

Hangzhou (Fig. 6), implying there may be some imperfections in the nocturnal chemistry of CMAQ. Nevertheless, the performance of CMAQ model is comparable to the other applications (Gonçalves et al., 2009; Li et al., 2012; Zhu et al., 2015). Compared to these previous related studies, the simulation in this study attains an acceptable and satisfactory result. Thus, the consistency of simulation and observation demonstrates that the modeling results are capable of capturing and reproducing the characteristics and changes of photochemical pollutants and can be used to provide valuable insights into the governing processes of this $\mathrm{O}_{3}$ episode.

\subsection{Characteristics of the vertical airflows}

Figure 7 presents the daytime vertical wind velocity as well as the vertical distribution of $\mathrm{O}_{3}$ concentrations from 116.5 to $122.9^{\circ} \mathrm{E}$ along the latitude of $31.40^{\circ} \mathrm{N}$ (where Shanghai is located) during 7-12 August 2013. The simulation results clearly illustrate that there are strong downward airflows over the YRD region during the period of the regional high-level $\mathrm{O}_{3}$ pollution, which can be attributed to the fact that these areas are under the control of the subtropical high and the sinking airflow is predominant (as discussed in Sect. 3.2).

From 7 to 9 August 2013, except for the aforementioned regional sinking airflows, there are still some local thermal circulations continually occurring at the lower atmospheric layers $(<2 \mathrm{~km})$ along the vertical cross section of HZ-NJ. These circulations are related to urban heat islands. Usually high pressures are accompanied by more stagnant and fair dry weather, so the upward and the downward flows caused by urban-breeze circulations can easily appear in the urban areas. For the vertical distribution of $\mathrm{O}_{3}$, its high concentrations $(>50 \mathrm{ppb})$ generally appear from the surface to $1.5 \mathrm{~km}$ height above the cities. As discussed in Sect. 3.2, air pollutants tend to be trapped on the ground due to the regional sinking airflows. Moreover, the local circulations over the cities make the urban areas to be the convergence zones, and thereby more air pollutants can be accumulated in and around these cities. Under the weather conditions induced by 


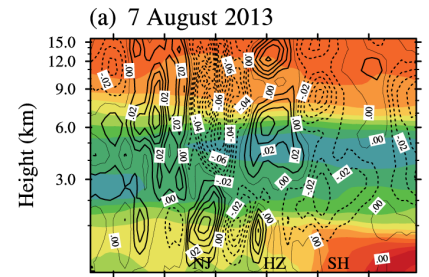

$117^{\circ} \mathrm{E} 118^{\circ} \mathrm{E} 119^{\circ} \mathrm{E} 120^{\circ} \mathrm{E} 121^{\circ} \mathrm{E} 122^{\circ} \mathrm{E}$ (d) 10 August 2013

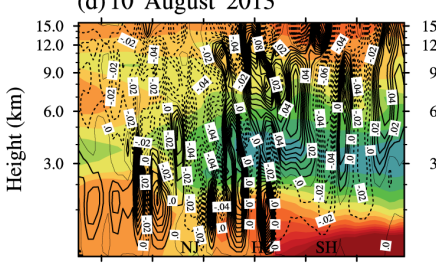

$117^{\circ} \mathrm{E} 118^{\circ} \mathrm{E} 119^{\circ} \mathrm{E} 120^{\circ} \mathrm{E} 121^{\circ} \mathrm{E} 122^{\circ} \mathrm{E}$

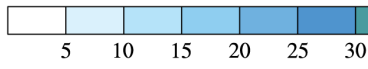

(b) 8 August 2013

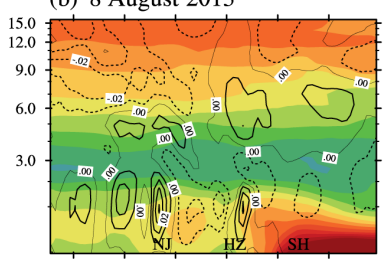

$117^{\circ} \mathrm{E} 118^{\circ} \mathrm{E} 119^{\circ} \mathrm{E} 120^{\circ} \mathrm{E} 121^{\circ} \mathrm{E} 122^{\circ} \mathrm{E}$ (e) 11 August 2013 (c) 9 August 2013

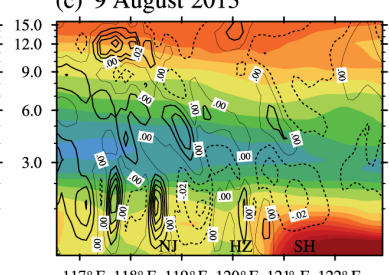

$117^{\circ} \mathrm{E} 118^{\circ} \mathrm{E} 119^{\circ} \mathrm{E} 120^{\circ} \mathrm{E} 121^{\circ} \mathrm{E} 122^{\circ} \mathrm{E}$ (f) 12 August 2013

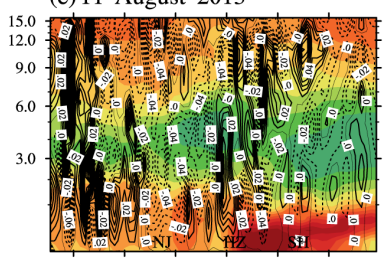

$117^{\circ} \mathrm{E} 118^{\circ} \mathrm{E} 119^{\circ} \mathrm{E} 120^{\circ} \mathrm{E} 121^{\circ} \mathrm{E} 122^{\circ} \mathrm{E}$

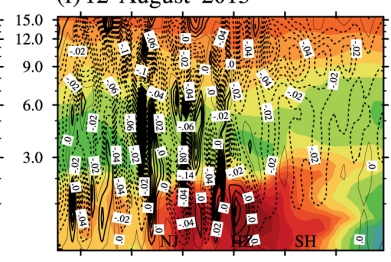

$117^{\circ} \mathrm{E} 118^{\circ} \mathrm{E} 119^{\circ} \mathrm{E} 120^{\circ} \mathrm{E} 121^{\circ} \mathrm{E} 122^{\circ} \mathrm{E}$

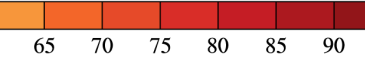

Ozone concentration (ppb)

Figure 7. Simulated daytime vertical wind velocity and vertical distribution of $\mathrm{O}_{3}$ concentrations from 116.5 to $122.9^{\circ} \mathrm{E}$ along the latitude of $31.40^{\circ} \mathrm{N}$ (where Shanghai is located) during 7 to 12 August 2013. The marks of SH, HZ and NJ point out the longitudes of Shanghai, Hangzhou and Nanjing, respectively. The dotted lines show the negative wind speeds and represent downward airflow, while the solid lines show the positive wind speeds and zero vertical velocity. The interval is $0.01 \mathrm{~m} \mathrm{~s}^{-1}$.

the subtropical high, such as high air temperature, stronger solar radiation and less water vapor, the chemical reactions between the built-up air pollutants can be enhanced to form the high-level $\mathrm{O}_{3}$ pollution. Additionally, Fig. 7a-c also show that there are maximum $\mathrm{O}_{3}$ concentrations ( $>90 \mathrm{ppb}$ ) occurring near the surface in and around SH. This phenomenon should be explained by the fact that the coastal city $(\mathrm{SH})$ is firstly affected by Typhoon Utor.

From 10 to 12 August, with the approaching of Typhoon Utor, the vertical air movements over the YRD region are not restricted at the lower atmosphere anymore. As shown in Fig. $7 d-f$, there are stronger downward airflows from the surface to the top of troposphere. As discussed in Sect. 3.2, the YRD cities are at the front of the moving typhoon system, so the peripheral circulation of Typhoon Utor may enhance the sinking of atmosphere, which can lead to higher air temperature, lower humidity and stronger solar radiation. Affected by the enhanced downward air movement as well as the relevant changes of meteorological conditions, $\mathrm{O}_{3}$ concentrations over the YRD region maintain a high pollution level, with the $\mathrm{O}_{3}$ concentrations over $60 \mathrm{ppb}$ below the height of $1.5 \mathrm{~km}$ (Fig. 7d-f). Furthermore, the high value center of $\mathrm{O}_{3}$ concentrations $(>90 \mathrm{ppb}$ ) moves westwards during 1012 August, implying that the peripheral circulation of Typhoon Utor can drive the air from the coastal areas to the inland areas.

The vertical changes of wind velocity and $\mathrm{O}_{3}$ concentrations above Shanghai, Hangzhou and Nanjing are further illustrated in Fig. 8. Similarly, the atmospheric subsidence can also be found in the troposphere (usually occur at more than $1 \mathrm{~km}$ above the surface) during the period of high-level
$\mathrm{O}_{3}$ pollution. With respect to Shanghai, affected by the extremely high temperature, more active photochemical reactions lead to higher $\mathrm{O}_{3}$ concentrations in the whole atmospheric boundary layer. The downward airflows induced by the subtropical high trap and enhance the accumulation of surface $\mathrm{O}_{3}$ as time passes. Thus, high $\mathrm{O}_{3}$ concentrations are formed below $2 \mathrm{~km}$ above the urban areas of Shanghai, and the high concentration centers occur near the surface below $500 \mathrm{~m}$. It is interesting that $\mathrm{O}_{3}$ concentration on 8 August is comparatively lower, which can be seen in Fig. 2 as well. This phenomenon can be explained by the fact that the transient upward airflow occurs at above $300 \mathrm{~m}$ over Shanghai and inhibits the accumulation of the $\mathrm{O}_{3}$ pollution at the surface (shown in Fig. 8a). Additionally, Fig. 8a also presents the possible effects of Typhoon Utor on the formation of $\mathrm{O}_{3}$. On 10 August, when the typhoon system approaches the eastern coastal areas of China, the sinking air above Shanghai is apparently strengthened and thereby enhances the intensity of $\mathrm{O}_{3}$ pollution as well as the scope of the pollution. However, after 12 August, when Typhoon Utor changes the wind and even impacts the subtropical high, high temperature is alleviated and the built-up $\mathrm{O}_{3}$ is transported to other places. Thus, the pollution is mitigated. As to Hangzhou (Fig. 8b), from 7 to 9 August, owing to weaker photochemical reactions, lower $\mathrm{O}_{3}$ concentrations than those in Shanghai are found in the boundary layer. However, the $\mathrm{O}_{3}$ concentration can exceed the national standard from 10 to 12 August (Fig. 2), which should be influenced by the typhoon system. The influence process is similar to the above discussion for Shanghai; that is, the upper downward airflows (over $1 \mathrm{~km}$ above the surface) are enhanced significantly since $10 \mathrm{Au}$ - 
(a) Shanghai

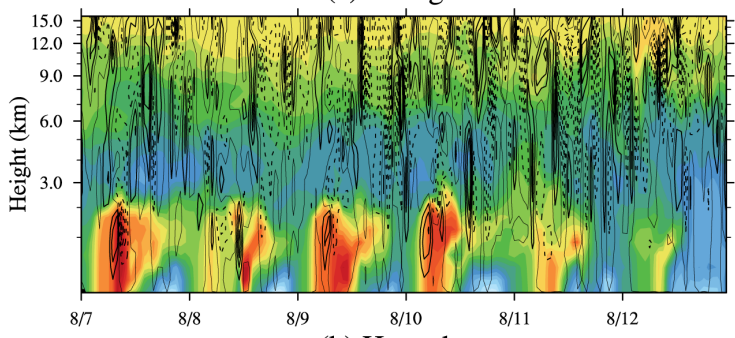

(b) Hangzhou

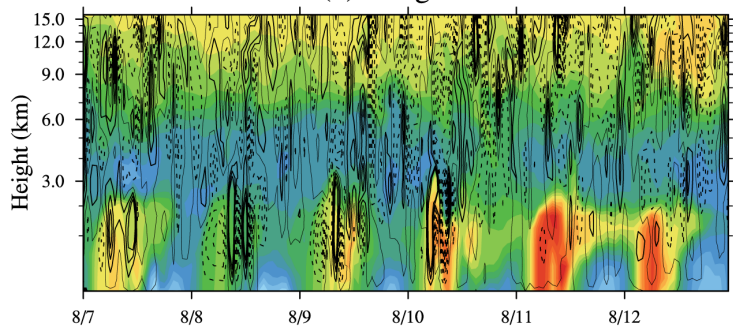

(c) Nanjing

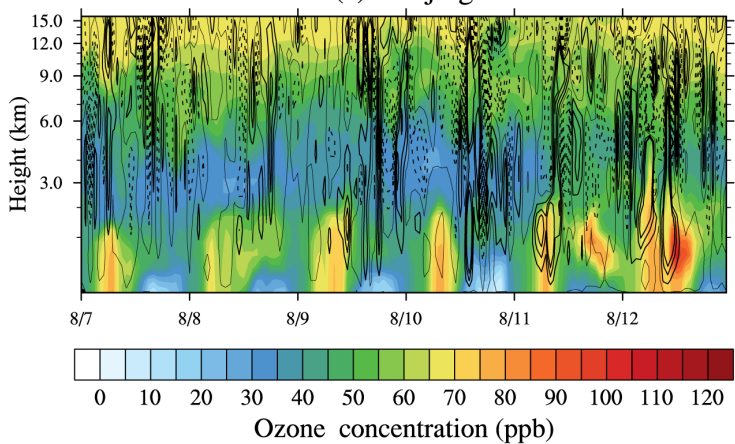

Figure 8. Temporal variations of the vertical wind velocity and the vertical distribution of $\mathrm{O}_{3}$ concentrations above (a) Shanghai, (b) Hangzhou and (c) Nanjing from 7 to 12 August 2013. The dotted lines show the negative wind speeds and represent the downward airflows, while the solid lines show the positive wind speeds and zero vertical velocity. The interval is $0.005 \mathrm{~m} \mathrm{~s}^{-1}$.

gust. However, for Nanjing, the $\mathrm{O}_{3}$ concentration does not exceed the national $\mathrm{O}_{3}$ standard during 7-12 August (Figs. 2 and 8), which should be attributed to the fact that Nanjing is far away from the coastal areas and thereby hardly affected by the downward flow in the typhoon periphery. Though the $\mathrm{O}_{3}$ concentration in Nanjing increases on 12 August, it should mainly be caused by the local photochemical reactions because the vertical movement below $2 \mathrm{~km}$ above Nanjing is dominated by upward airflows.

It also should be mentioned that the near-surface vertical velocities around these cities are much lower than those at higher altitudes (Fig. 8). Especially in the planetary boundary layer $(<1 \mathrm{~km})$, lots of zero-velocity lines appear near the ground. This phenomenon may be related to the upward airflow caused by urban heat islands. Thus, the maximum centers of $\mathrm{O}_{3}$ occur near the surface below $500 \mathrm{~m}$, and the vertical diffusion process plays a more important role in the ac- cumulation of surface $\mathrm{O}_{3}$. The essential role of the vertical diffusion process in the $\mathrm{O}_{3}$ episode is similar to that reported by Zhu et al. (2015).

\subsection{Process analysis for ozone formation}

\subsubsection{Typical cities in the YRD region}

Figure 9 shows the daytime mean contributions of different atmospheric processes to the formation of $\mathrm{O}_{3}$ in $\mathrm{SH}, \mathrm{NJ}$ and $\mathrm{HZ}$ at the first modeling layer from 4 to 15 August 2013. As shown in the figure, for all cities during this period, the major contributors to high $\mathrm{O}_{3}$ concentrations include the VDIF, the DDEP, the CHEM and the total advection (TADV). TADV is the sum of the HADV and the ZADV. In this study, HADV and ZADV are considered together as TADV because they are inevitably linked as the inseparable parts of air circulation. As discussed in Sect. 3.2, the strong sinking air causes slow wind on the ground and little clouds in the sky, so the contributions of HDIF and CLDS are quite small during this episode.

In the first layer of the urban areas of Shanghai (Fig. 9a), the averaged contributions from the VDIF, the CHEM, the TADV and the DDEP during the daytime of 4-15 August are $9.95,10.10,-11.74$ and $-7.28 \mathrm{ppb} \mathrm{h}^{-1}$, respectively. Obviously, VDIF and CHEM exhibit significant positive contributions to $\mathrm{O}_{3}$ during most days, while TADV and DDEP mainly show the consumption contributions. The sinking air caused by the weather system discussed in Sect. 3.2 can trap heat and air pollutants on the ground and make VDIF be the most import source of surface $\mathrm{O}_{3}$. Meanwhile, the hotter and dryer weather with more sunshine, above $40^{\circ} \mathrm{C}$ and comparatively low relative humidity (shown in Fig. 4), which is related to the sinking air, can enhance the photochemical reactions. Thus, CHEM can form more $\mathrm{O}_{3}$ on the ground. Compared with the time series of CHEM and DDEP in which there are no obvious fluctuations, the values of VDIF and TADV significantly change with the time, with the daytime mean contributions varying from 3.99 to $28.45 \mathrm{ppb} \mathrm{h}^{-1}$ for VDIF and from -2.56 to $-28.13 \mathrm{ppb} \mathrm{h}^{-1}$ for TADV. These time variations should be related to the changes of vertical air movement. For example, the value of VDIF on 8 August is only $3.99 \mathrm{ppbh}^{-1}$, which can be attributed to the local transient upward airflow over Shanghai (shown in Fig. 8a). On 10 August, however, VDIF can contribute $28.45 \mathrm{ppb} \mathrm{O}_{3} \mathrm{~h}^{-1}$, which may be related to the enhanced downward air movement caused by the peripheral circulation of Typhoon Utor. Moreover, during the highlevel $\mathrm{O}_{3}$ episode from 7 to 12 August, the mean values for VDIF, CHEM, TADV and DDEP are 13.41, 11.21, -8.37 and $-14.74 \mathrm{ppbh}^{-1}$. However, after 12 August, the mean contributions of VDIF, CHEM, TADV and DDEP decrease to $5.35,9.53,-5.52$ and $-10.85 \mathrm{ppb} \mathrm{h}^{-1}$. These reductions should be related to the process that the subtropical high moves eastward and northward, forced by Typhoon Utor 

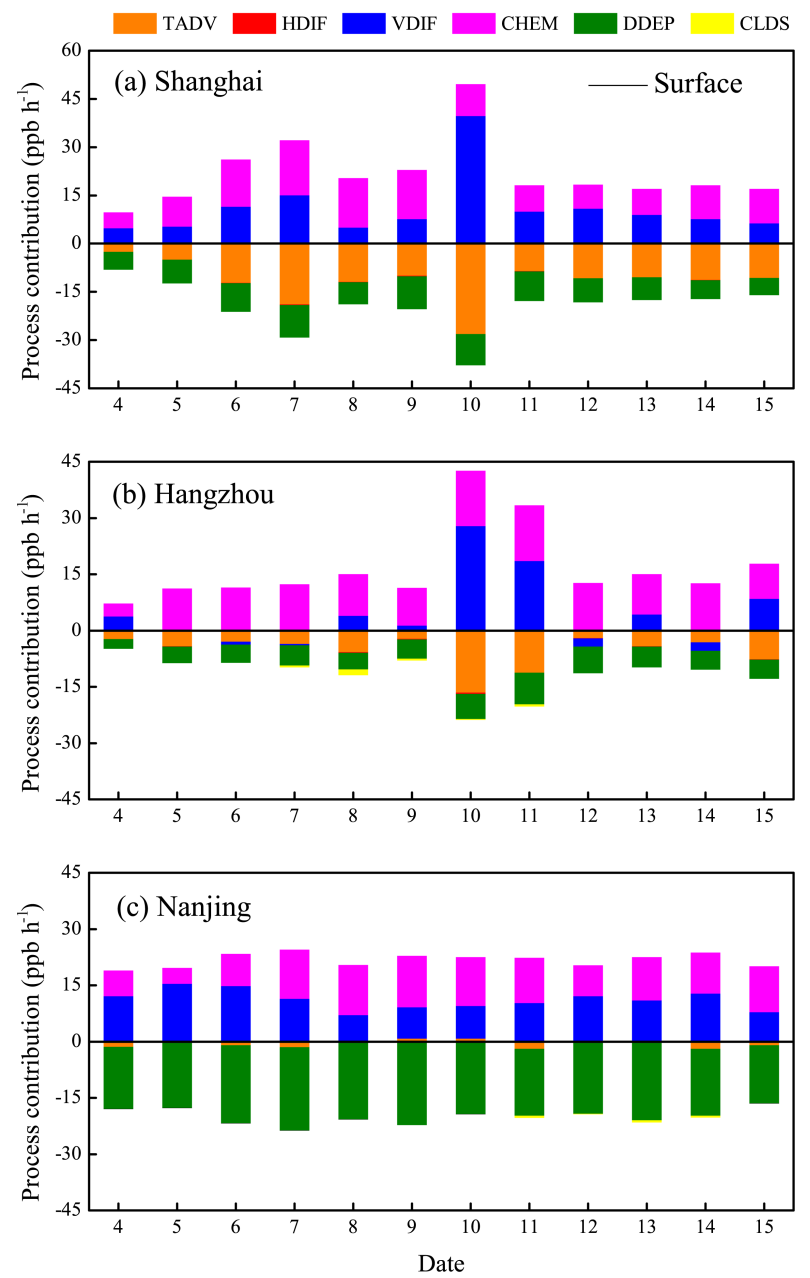

Figure 9. Variations of the daytime mean values for the contributions of individual processes to $\mathrm{O}_{3}$ formation in (a) Shanghai, (b) Hangzhou and (c) Nanjing from 4 to 15 August 2013 at the surface layer. The contributors include the total advection (TADV), the horizontal diffusion (HDIF), the vertical diffusion (VDIF), the gasphase chemistry (CHEM), the dry deposition (DDEP) and the cloud processes with the aqueous chemistry (CLDS).

(Fig. 5d). By quantifying the relative importance of each process to $\mathrm{O}_{3}$ formation, the IPR analysis provides a fundamental explanation for the synthetical influence of the high pressure and the typhoon system, which has been discussed in Sects. 3.2 and 4.1, and further illustrates the exact mechanism.

Figure $9 \mathrm{~b}$ presents the result of IPR analysis for Hangzhou. During 4-15 August, VDIF and CHEM are the major source of surface $\mathrm{O}_{3}$ with the average contribution of $5.36 \mathrm{ppbh}^{-1}$ for VDIF and $10.97 \mathrm{ppbh}^{-1}$ for CHEM, while TADV and DDEP are two important sinks for $\mathrm{O}_{3}$ with the average contribution of $-9.63 \mathrm{ppb} \mathrm{h}^{-1}$ for TADV and $-5.14 \mathrm{ppb} \mathrm{h}^{-1}$ for DDEP. Synthetically impacted by western Pacific subtropical high and Typhoon Utor, the mean contributions during the $\mathrm{O}_{3}$ episode (from 7 to 12 August) for VDIF, CHEM, TADV and
DDEP increase to $7.21,12.61,-11.51$ and $-5.92 \mathrm{ppbh}^{-1}$, respectively. The highest VDIF contribution occurs on 10 11 August, and the over-standard of $\mathrm{O}_{3}$ concentration appears on 10-12 August as well, which may be attributed to the effect of typhoon's peripheral circulation, implying Typhoon Utor also plays an essential role in the formation of $\mathrm{O}_{3}$ pollution in Hangzhou. After Typhoon Utor approaches close enough to Hangzhou, the wind direction is mainly dominated by the southeast wind (Fig. 4b), and the mean values of VDIF, CHEM, TADV and DDEP finally decrease to 4.84, $10.08,-8.92$ and $-4.78 \mathrm{ppbh}^{-1}$, respectively. In a word, Hangzhou is located close to Shanghai, so the temporal variations of VDIF, CHEM, TADV and DDEP in Hangzhou are similar to those in Shanghai.

However, the similar variation pattern of VDIF, CHEM, TADV and DDEP occurring in Shanghai and Hangzhou does not appear in Nanjing. As shown in Fig. 9c, the mean contributions of VDIF, CHEM, TADV and DDEP to surface $\mathrm{O}_{3}$ in Nanjing are $11.31,9.55-1.34$ and $-17.57 \mathrm{ppbh}^{-1}$ during the whole period, while the values during 7-12 August are $10.32,10.70,-0.99$ and $-18.42 \mathrm{ppbh}^{-1}$. There are no apparent fluctuations or sudden increases of these contributors during the period from 4 to 15 August or the $\mathrm{O}_{3}$ concentration (Fig. 2), temperature and relative humidity (Fig. 4a), implying Nanjing is generally under the control of the western Pacific subtropical high and can hardly be affected by the typhoon system. As a typical city in the northwest inland area of the YRD region (NIR), Nanjing is located far away from the sea, which means it may not be easily affected by the peripheral circulation of the typhoon system.

Additionally, at the altitude of 500 and $1500 \mathrm{~m}$ above Shanghai, Nanjing and Hangzhou (not shown), CHEM is also the major contributor to $\mathrm{O}_{3}$ formation, with the values a litter lower than those at the surface, suggesting that there are strong photochemical reactions in the whole boundary layer of these YRD cities. In contrast, VDIF has an opposite effect in the middle of the boundary layer, with the negative contributions for $\mathrm{O}_{3}$ of $-3.26 \mathrm{pph}^{-1}$ in Shanghai, $-2.37 \mathrm{ppb} \mathrm{h}^{-1}$ in Hangzhou and $-3.21 \mathrm{ppbh}^{-1}$ in Nanjing, respectively (not shown). The loss of $\mathrm{O}_{3}$ at higher atmospheric level caused by VDIF further proves the essential role of the downward vertical movement in this $\mathrm{O}_{3}$ episode.

\subsubsection{Spatial distribution of the contributors for the $\mathrm{O}_{3}$ episode over the YRD region}

Figure 10 demonstrates the spatial distribution of the daytime mean contributions of main processes (VDIF, CHEM, DDEP and TADV) to the ozone formation at the lowest modeling layer in domain 3 during this high-level $\mathrm{O}_{3}$ episode. The modeling results from 7 to 12 August are averaged to provide the mean values.

Similar to the results shown in Fig. 9, Fig. 10 illustrates that VDIF and CHEM exhibit significant positive contributions to $\mathrm{O}_{3}$ over the YRD region and the surrounding ar- 

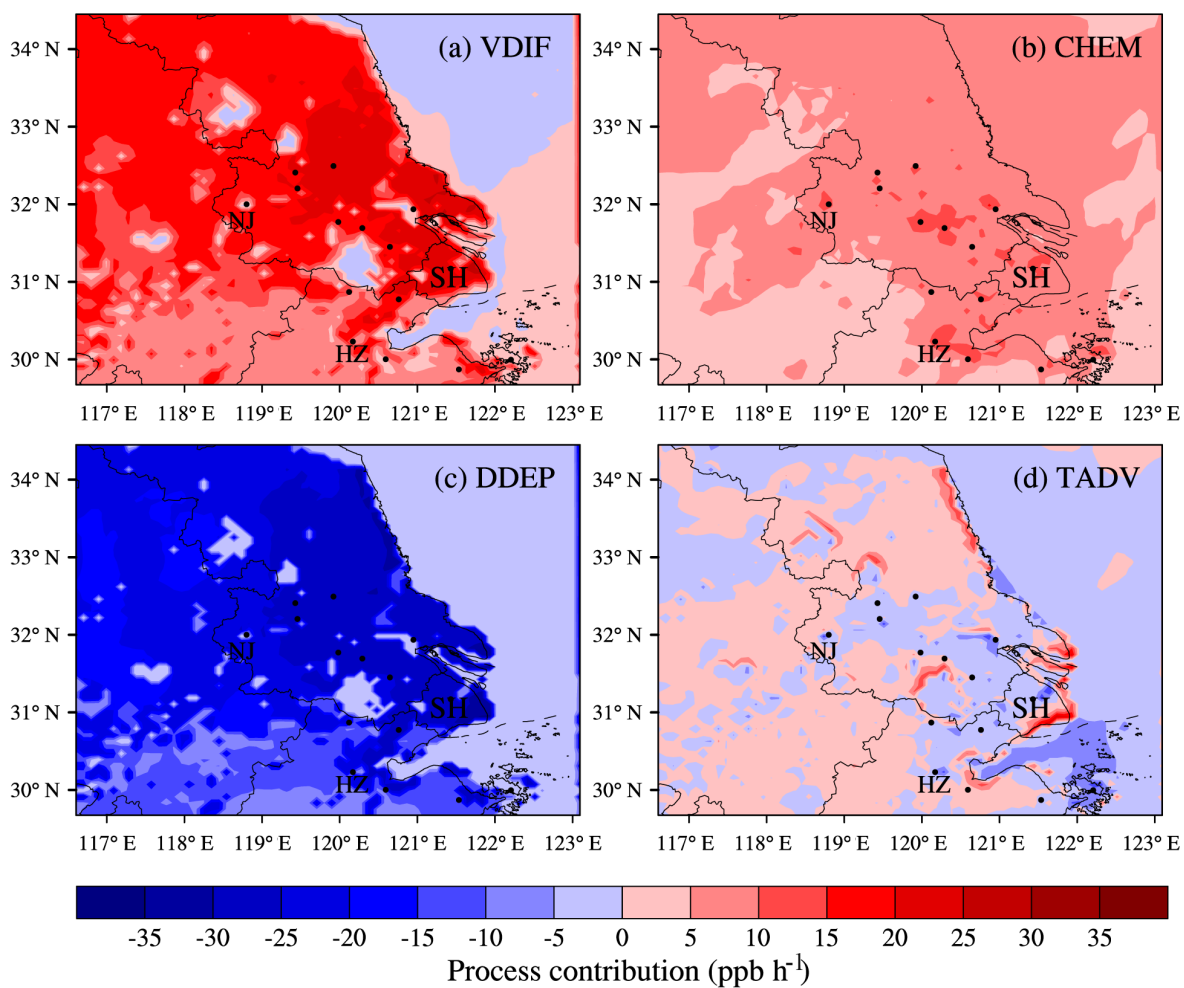

Figure 10. The daytime mean contributions of main processes to $\mathrm{O}_{3}$ formation over the YRD region, including (a) vertical diffusion (VDIF), (b) gas chemistry (CHEM), (c) dry deposition (DDEP) and (d) total advection (TADV). The values are averaged from 7 to 12 August 2013.

eas during the high-level $\mathrm{O}_{3}$ episode. The contributions of VDIF in domain 3 (Fig. 10a) range from 5 to $25 \mathrm{ppbh}^{-1}$, with the high values $\left(>20 \mathrm{ppbh}^{-1}\right)$ occurring in the southeast coastal areas. For CHEM (Fig. 10b), the contributions vary within the range of $0-15 \mathrm{ppbh}^{-1}$, with the high values over $10 \mathrm{ppbh}^{-1}$ appearing in and around the big cities. As discussed above, these regional positive contributions of VDIF and CHEM over domain 3 should be related to the facts that the whole region is under the control of the western Pacific subtropical high. With respect to the higher contributions of CHEM in the urban areas, they should be attributed to the spatial distribution of the emissions of $\mathrm{O}_{3}$ precursors, which is also higher in the cities. Furthermore, higher air temperature in the cities related to the urban heat island may enhance the chemical reactions and form more $\mathrm{O}_{3}$ in these areas as well.

For DDEP, it is the main critical factor of the consumption of $\mathrm{O}_{3}$, with the negative contributions varying from 0 to $-25 \mathrm{ppb} \mathrm{h}^{-1}$ over the modeling domain 3 (Fig. 10c). Small values usually occur on the water, which may be related to less air pollution over rivers, lakes and oceans. High values can be found on land, especially in the southeast coastal areas. For the contributions of TADV, the values in domain 3 range from -10 to $10 \mathrm{ppbh}^{-1}$, with the positive contributions generally occurring on land and the negative ones appearing on the water (Fig. 10d). The maximum positive contributions of TADV are usually found along the boundary between the land and the water, which should be explained by the facts that the land-sea breeze circulations can play an important role in the redistribution of the formed $\mathrm{O}_{3}$. On account of the high-pressure system and resulting sinking airflows in the YRD region, the background wind is relatively weak in comparison to the local atmospheric circulation, thus the sea breeze can easily bring more generated $\mathrm{O}_{3}$ to the seashore.

From the discussion in Sects. 3 and 4.2, it can be deduced that typhoon Utor plays an important role in the formation of ozone over the YRD region during 10-12 August. To clearly clarify the effect of the typhoon system in this $\mathrm{O}_{3}$ pollution episode, we firstly average the modeling results of VDIF, CHEM, DDEP and TADV during 10-12 August to show their contributions to $\mathrm{O}_{3}$ formation when the typhoon system plays an important role. Secondly, the modeling results of these processes from 7 to 9 August are also averaged to provide their contributions when only the subtropical high dominates the episode. Finally, the differences of the contributions of VDIF, CHEM, DDEP and TADV between the period of 79 and 10-12 August are calculated to reveal the role of the typhoon system in this severe high $\mathrm{O}_{3}$ episode (Fig. 11). As shown in Fig. 11a, when YRD is affected by the peripheral circulation of Typhoon Utor, the contributions of VDIF over the YRD region increase by $0-15 \mathrm{ppbh}^{-1}$, with the higher 

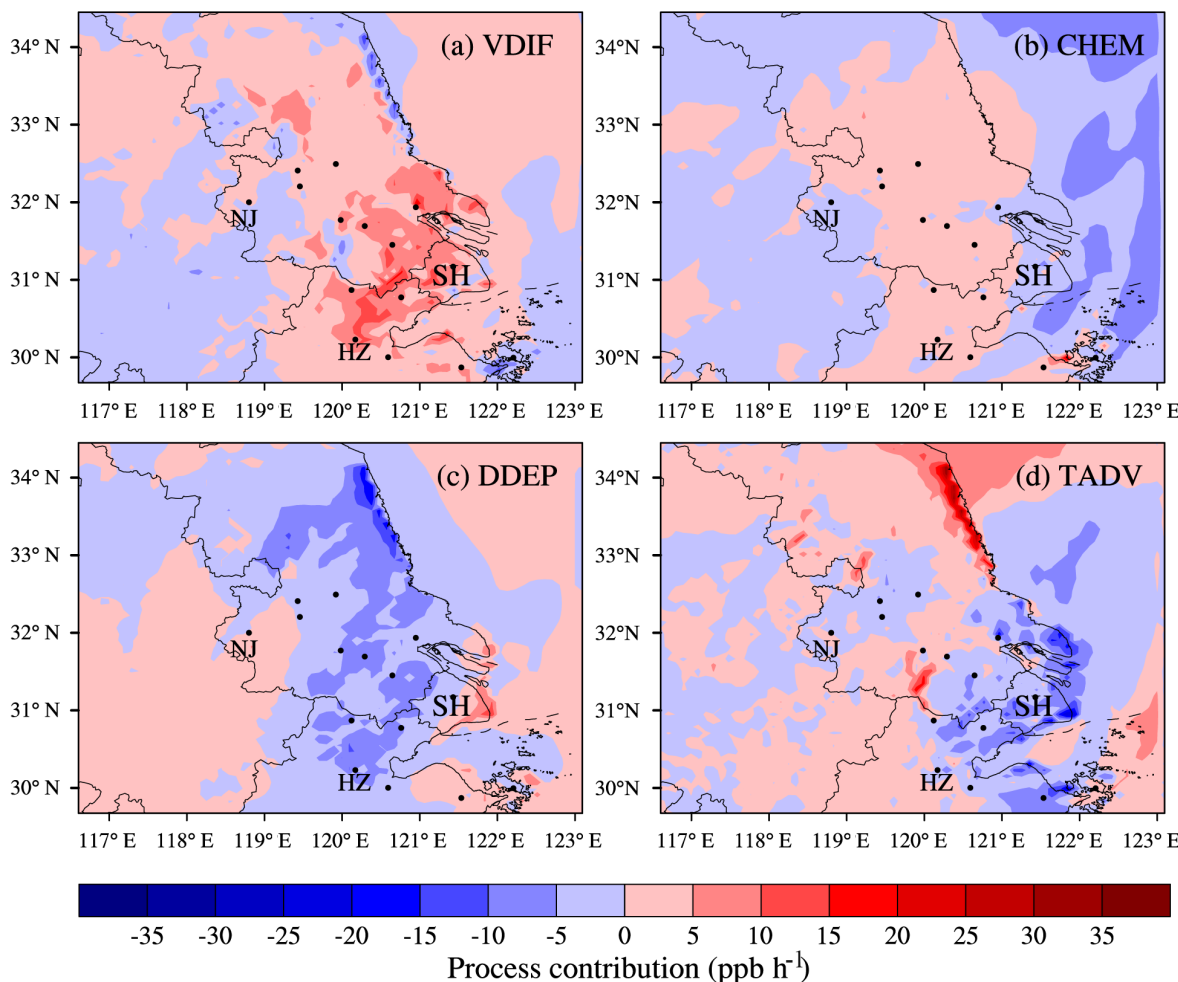

Figure 11. The difference of daytime mean contributions of main processes to $\mathrm{O}_{3}$ formation over the YRD region between the period of $10-$ 12 and 7-9 August, including (a) vertical diffusion (VDIF), (b) gas chemistry (CHEM), (c) dry deposition (DDEP) and (d) total advection (TADV).

increment values $\left(>30 \mathrm{ppbh}^{-1}\right)$ occurring in the SCR and CIR, implying that SCR and CIR can be largely affected by the peripheral subsidence airflows of the typhoon system. As to the contributions of CHEM, the increases caused by the typhoon system are $0-5 \mathrm{ppbh}^{-1}$ over the YRD region, and the higher increment also appears in the coastal areas (Fig. 11b). For DDEP, influenced by typhoon Utor, its negative contributions decrease by up to $-20 \mathrm{ppbh}^{-1}$, with the largest reduction along the coastline (Fig. 11c). For TADV, with the approaching of typhoon Utor, the contributions of TADV particularly decrease by $0-20 \mathrm{ppb} \mathrm{h}^{-1}$, especially in the SCR (Fig. 11d).

In all, during this high-level $\mathrm{O}_{3}$ pollution episode, more active photochemical reactions and the vertical diffusion play a significant role in the accumulation of surface $\mathrm{O}_{3}$ over the YRD region. The major driving factor should be the western Pacific subtropical high. Moreover, the changes in the contributions of VDIF, CHEM, DDEP and TADV between 7-9 and 10-12 August exhibit a similar spatial pattern with the high values mostly concentrating in the southeast coastal areas (Fig. 12), implying the Typhoon Utor also plays a collaborative effect.

\section{Conclusions}

In this study, the characteristics and the essential impact factors of a typical regional continuous $\mathrm{O}_{3}$ pollution over the YRD region are investigated by means of observational analysis and numerical simulation. The episode lasted for nearly a week from 7 to 12 August 2013, with the $\mathrm{O}_{3}$ concentration exceeding the national air quality standard in more than half of the cities over the YRD region. The analysis of weather systems and the modeling results from WRF/CMAQ all illustrate that the continuous strong western Pacific subtropical high is the leading factor of the abnormally high temperature weather and the heavy $\mathrm{O}_{3}$ pollution by inducing more sinking air to trap heat as well as air pollutants at the surface. Meanwhile, the development of this episode is closely related to the movement of Typhoon Utor as well. The temporal variations of the vertical wind velocity and $\mathrm{O}_{3}$ concentrations show that when the YRD region is at the front of moving typhoon system, the downward airflow is enhanced in the boundary layer with fine weather, and thereby the air pollutants are trapped and accumulated near the surface. Moreover, in the last stage of the $\mathrm{O}_{3}$ episode, the activity of Typhoon Utor weakens the strength of the subtropical high and forces it to retreat easterly and move northward, and the prevailing southeasterly surface wind related to the approaching 
of Typhoon Utor contributes to the mitigation of the $\mathrm{O}_{3}$ pollution.

The IPR analysis implemented in CMAQ is specially carried out to quantify the relative contributions of individual processes and give a fundamental explanation. During the high-level $\mathrm{O}_{3}$ episode from 7 to 12 August, the VDIF and the CHEM exhibit significant positive contributions to surface $\mathrm{O}_{3}$ over the YRD region, with the high values over $20 \mathrm{ppb} \mathrm{h}^{-1}$ for VDIF and over $10 \mathrm{ppbh}^{-1}$ for CHEM. The DDEP is the major sink of surface $\mathrm{O}_{3}$, while the TADV can give the positive contribution on land and the negative contribution on the water. Moreover, on 10-12 August, the YRD region is apparently affected by the periphery circulation of Typhoon Utor, with the contributions of VDIF over the YRD region increasing by $0-15 \mathrm{ppb} \mathrm{h}^{-1}$, the contributions of CHEM increasing by $0-5 \mathrm{ppb} \mathrm{h}^{-1}$ and the contributions of DDEP and TADV decreasing. Especially in the coastal cities, such as Shanghai and Hangzhou, the effects of the typhoon system are more obvious. In contrast, the cities in the northwest inland area of the YRD region, which are far away from the sea, can hardly be affected by the typhoon system. In the end, when the typhoon system significantly weakens the high pressure system, the contributions of VDIF, CHEM, TADV and DDEP decrease to a low level in all cities.

The WRF/CMAQ modeling system shows a relatively good performance in simulation of the $\mathrm{O}_{3}$ episode, with the simulated meteorological conditions and air pollutant concentrations basically in agreement with the observations in most YRD cities. Our results in this study can provide an insight for the formation mechanism of regional $\mathrm{O}_{3}$ pollution in East Asia and help to forecast the $\mathrm{O}_{3}$ pollution synthetically impacted by the western Pacific subtropical high and the tropical cyclone system.

\section{Data availability}

The air quality monitoring records are available at http://106. 37.208.233:20035. The weather charts are accessible at http: //www.kma.go.kr/chn/weather/images/analysischart.jsp. The meteorological data are available at http://weather.uwyo.edu/ wyoming/.

Acknowledgements. This study was supported by the National Natural Science Foundation of China (41475122, 91544230, 41575145, 41621005), the National Special Fund for Environmental Protection Research in the Public Interest (201409008) and EU 7th Framework Marie Curie Actions IRSES project REQUA (PIRSES-GA-2013-612671). The authors would like to thank Hongli Wang from Shanghai Academy of Environmental Sciences for providing VOCs observation data, Xiaoxun Xie for preliminary data processing and the anonymous reviewers for their constructive and precious comments on this paper.

Edited by: J. Chen

Reviewed by: three anonymous referees

\section{References}

An, X., Zhu, T., Wang, Z., Li, C., and Wang, Y.: A modeling analysis of a heavy air pollution episode occurred in Beijing, Atmos. Chem. Phys., 7, 3103-3114, doi:10.5194/acp-7-3103-2007, 2007.

Byun, D. and Schere, K. L.: Review of the governing equations, computational algorithms, and other components of the models3 Community Multiscale Air Quality (CMAQ) modeling system, Appl. Mech. Rev., 59, 51-77, doi:10.1115/1.2128636, 2006.

Chan, C. K. and Yao, X.: Air pollution in mega cities in China, Atmos. Environ., 42, 1-42, doi:10.1016/j.atmosenv.2007.09.003, 2008.

Chen, D., Zhou, B., Beirle, S., Chen, L. M., and Wagner, T.: Tropospheric $\mathrm{NO}_{2}$ column densities deduced from zenith-sky DOAS measurements in Shanghai, China, and their application to satellite validation, Atmos. Chem. Phys., 9, 3641-3662, doi:10.5194/acp-9-3641-2009, 2009.

Chen, F. and Dudhia, J.: Coupling an advanced land surfacehydrology model with the Penn State-NCAR MM5 modeling system, Part I: Model implementation and sensitivity, Mon. Weather Rev., 129, 569-585, doi:10.1175/15200493(2001)129<0569:Caalsh>2.0.Co;2, 2001.

Cheng, W. L., Lai, L. W., Den, W., Wu, M. T., Hsueh, C. A., Lin, P. L., Pai, C. L., and Yan, Y. L.: The relationship between typhoons' peripheral circulation and ground-level ozone concentrations in central Taiwan, Environ. Monit. Assess., 186, 791804, doi:10.1007/s10661-013-3417-7, 2014.

Chiqueto, J. and Silva, M. E. S.: São Paulo "Surface Ozone Layer" and the atmosphere: characteristics of tropospheric ozone concentrations in the city and how the atmosphere influences them, VDM Verlag Dr. Muller, Saarbrücken, 2010.

Crutzen, P.: A discussion of the chemistry of some minor constituents in the stratosphere and troposphere, Pure Appl. Geophys., 106, 1385-1399, 1973.

Ding, A. J., Fu, C. B., Yang, X. Q., Sun, J. N., Zheng, L. F., Xie, Y. N., Herrmann, E., Nie, W., Petäjä, T., Kerminen, V.-M., and Kulmala, M.: Ozone and fine particle in the western Yangtze River Delta: an overview of $1 \mathrm{yr}$ data at the SORPES station, Atmos. Chem. Phys., 13, 5813-5830, doi:10.5194/acp-13-58132013, 2013.

Duan, J. C., Tan, J. H., Yang, L., Wu, S., and Hao, J. M.: Concentration, sources and ozone formation potential of volatile organic compounds (VOCs) during ozone episode in Beijing, Atmos. Res., 88, 25-35, doi:10.1016/j.atmosres.2007.09.004, 2008.

Emmons, L. K., Walters, S., Hess, P. G., Lamarque, J.-F., Pfister, G. G., Fillmore, D., Granier, C., Guenther, A., Kinnison, D., Laepple, T., Orlando, J., Tie, X., Tyndall, G., Wiedinmyer, C., Baughcum, S. L., and Kloster, S.: Description and evaluation of the Model for Ozone and Related chemical Tracers, version 4 (MOZART-4), Geosci. Model Dev., 3, 43-67, doi:10.5194/gmd3-43-2010, 2010.

Fann, N. and Risley, D.: The public health context for $\mathrm{PM}_{2.5}$ and ozone air quality trends, Air Qual. Atmos. Hlth., 6, 1-11, doi:10.1007/s11869-010-0125-0, 2013.

Feng, Z. W., Jin, M. H., Zhang, F. Z., and Huang, Y. Z.: Effects of ground-level ozone (O-3) pollution on the yields of rice and winter wheat in the Yangtze River Delta, J. Environ. Sci.-China, 15, 360-362, 2003. 
Foley, K. M., Roselle, S. J., Appel, K. W., Bhave, P. V., Pleim, J. E., Otte, T. L., Mathur, R., Sarwar, G., Young, J. O., Gilliam, R. C., Nolte, C. G., Kelly, J. T., Gilliland, A. B., and Bash, J. O.: Incremental testing of the Community Multiscale Air Quality (CMAQ) modeling system version 4.7, Geosci. Model Dev., 3, 205-226, doi:10.5194/gmd-3-205-2010, 2010.

Gao, J. H., Bin, Z., Xiao, H., Kang, H. Q., Hou, X. W., and Shao, P.: A case study of surface ozone source apportionment during a high concentration episode, under frequent shifting wind conditions over the Yangtze River Delta, China, Sci. Total Environ., 544, 853-863, doi:10.1016/j.scitotenv.2015.12.039, 2016.

Geng, F. H., Tie, X. X., Xu, J. M., Zhou, G. Q., Peng, L., Gao, W., Tang, X., and Zhao, C. S.: Characterizations of ozone, $\mathrm{NO}_{x}$, and VOCs measured in Shanghai, China, Atmos. Environ., 42, 68736883, doi:10.1016/j.atmosenv.2008.05.045, 2008.

Gonçalves, M., Jiménez-Guerrero, P., and Baldasano, J. M.: Contribution of atmospheric processes affecting the dynamics of air pollution in South-Western Europe during a typical summertime photochemical episode, Atmos. Chem. Phys., 9, 849-864, doi:10.5194/acp-9-849-2009, 2009.

Grell, G. A. and Devenyi, D.: A generalized approach to parameterizing convection combining ensemble and data assimilation techniques, Geophys. Res. Lett., 29, 169310, doi:10.1029/2002GL015311, 2002.

Guo, H., Jiang, F., Cheng, H. R., Simpson, I. J., Wang, X. M., Ding, A. J., Wang, T. J., Saunders, S. M., Wang, T., Lam, S. H. M., Blake, D. R., Zhang, Y. L., and Xie, M.: Concurrent observations of air pollutants at two sites in the Pearl River Delta and the implication of regional transport, Atmos. Chem. Phys., 9, 73437360, doi:10.5194/acp-9-7343-2009, 2009.

Han, S. Q., Bian, H., Feng, Y. C., Liu, A. X., Li, X. J., Zeng, F., and Zhang, X. L.: Analysis of the Relationship between $\mathrm{O}_{3}, \mathrm{NO}$ and $\mathrm{NO}_{2}$ in Tianjin, China, Aerosol Air Qual. Res., 11, 128-139, doi:10.4209/aaqr.2010.07.0055, 2011.

Hong, S. Y., Dudhia, J., and Chen, S. H.: A revised approach to ice microphysical processes for the bulk parameterization of clouds and precipitation, Mon. Weather Rev, 132, 103120, doi:10.1175/1520-0493(2004)132<0103:Aratim>2.0.Co;2, 2004.

Hong, S. Y., Noh, Y., and Dudhia, J.: A new vertical diffusion package with an explicit treatment of entrainment processes, Mon. Weather Rev., 134, 2318-2341, doi:10.1175/Mwr3199.1, 2006.

Huang, J. P., Fung, J. C. H., Lau, A. K. H., and Qin, Y.: Numerical simulation and process analysis of typhoon-related ozone episodes in Hong Kong, J. Geophys. Res.-Atmos., 110, D05301, doi:10.1029/2004jd004914, 2005.

Huang, J. P., Fung, J. C. H., and Lau, A. K. H.: Integrated processes analysis and systematic meteorological classification of ozone episodes in Hong Kong, J. Geophys. Res.-Atmos., 111, D20309, doi:10.1029/2005jd007012, 2006.

Hung, C. H. and Lo, K. C.: Relationships between Ambient Ozone Concentration Changes in Southwestern Taiwan and Invasion Tracks of Tropical Typhoons, Adv. Meteorol., 2015, 402976, doi:10.1155/2015/402976, 2015.

Jenkin, M. E. and Clemitshaw, K. C.: Ozone and other secondary photochemical pollutants: chemical processes governing their formation in the planetary boundary layer, Atmos. Environ., 34, 2499-2527, doi:10.1016/S1352-2310(99)00478-1, 2000.
Jiang, F., Wang, T. J., Wang, T. T., Xie, M., and Zhao, H.: Numerical modeling of a continuous photochemical pollution episode in Hong Kong using WRF-chem, Atmos. Environ., 42, 8717-8727, doi:10.1016/j.atmosenv.2008.08.034, 2008.

Jiang, F., Zhou, P., Liu, Q., Wang, T. J., Zhuang, B. L., and Wang, X. Y.: Modeling tropospheric ozone formation over East China in springtime, J. Atmos. Chem., 69, 303-319, doi:10.1007/s10874012-9244-3, 2012.

Kim, H. J. and Wang, B.: Sensitivity of the WRF Model Simulation of the East Asian Summer Monsoon in 1993 to Shortwave Radiation Schemes and Ozone Absorption, Asia-Pac. J. Atmos. Sci., 47, 167-180, doi:10.1007/s13143-011-0006-y, 2011.

Lam, K. S., Wang, T. J., Wu, C. L., and Li, Y. S.: Study on an ozone episode in hot season in Hong Kong and transboundary air pollution over Pearl River Delta region of China, Atmos. Environ., 39, 1967-1977, doi:10.1016/j.atmosenv.2004.11.023, 2005.

Landry, J. S., Neilson, E. T., Kurz, W. A., and Percy, K. E.: The impact of tropospheric ozone on landscape-level merchantable biomass and ecosystem carbon in Canadian forests, Eur. J. Forest Res., 132, 71-81, doi:10.1007/s10342-012-0656-z, 2013.

Li, L., Chen, C. H., Huang, C., Huang, H. Y., Zhang, G. F., Wang, Y. J., Chen, M. H., Wang, H. L., Chen, Y. R., Streets, D. G., and $\mathrm{Fu}, \mathrm{J}$. M.: Ozone sensitivity analysis with the MM5-CMAQ modeling system for Shanghai, J. Environ. Sci.-China, 23, 11501157, doi:10.1016/S1001-0742(10)60527-X, 2011.

Li, L., Chen, C. H., Huang, C., Huang, H. Y., Zhang, G. F., Wang, Y. J., Wang, H. L., Lou, S. R., Qiao, L. P., Zhou, M., Chen, M. H., Chen, Y. R., Streets, D. G., Fu, J. S., and Jang, C. J.: Process analysis of regional ozone formation over the Yangtze River Delta, China using the Community Multi-scale Air Quality modeling system, Atmos. Chem. Phys., 12, 10971-10987, doi:10.5194/acp-12-10971-2012, 2012.

Li, M. M., Song, Y., Huang, X., Li, J. F., Mao, Y., Zhu, T., Cai, X. H., and Liu, B.: Improving mesoscale modeling using satellite-derived land surface parameters in the Pearl River Delta region, China, J. Geophys. Res.-Atmos., 119, 6325-6346, doi:10.1002/2014JD021871, 2014.

Li, M. M., Song, Y., Mao, Z. C., Liu, M. X., and Huang, X.: Impacts of thermal circulations induced by urbanization on ozone formation in the Pearl River Delta region, China, Atmos. Environ., 127, 382-392, doi:10.1016/j.atmosenv.2015.10.075, 2016.

Liao, J. B., Wang, T. J., Wang, X. M., Xie, M., Jiang, Z. Q., Huang, X. X., and Zhu, J. L.: Impacts of different urban canopy schemes in WRF/Chem on regional climate and air quality in Yangtze River Delta, China, Atmos. Res., 145, 226-243, doi:10.1016/j.atmosres.2014.04.005, 2014.

Liao, J. B., Wang, T. J., Jiang, Z. Q., Zhuang, B. L., Xie, M., Yin, C. Q., Wang, X. M., Zhu, J. L., Fu, Y., and Zhang, Y.: WRF/Chem modeling of the impacts of urban expansion on regional climate and air pollutants in Yangtze River Delta, China, Atmos. Environ., 106, 204-214, doi:10.1016/j.atmosenv.2015.01.059, 2015.

Liu, Q., Lam, K. S., Jiang, F., Wang, T. J., Xie, M., Zhuang, B. L., and Jiang, X. Y.: A numerical study of the impact of climate and emission changes on surface ozone over South China in autumn time in 2000-2050, Atmos. Environ., 76, 227-237, doi:10.1016/j.atmosenv.2013.01.030, 2013.

Liu, X. H., Zhang, Y., Xing, J., Zhang, Q. A., Wang, K., Streets, D. G., Jang, C., Wang, W. X., and Hao, J. M.: Understanding of regional air pollution over China using CMAQ, part II. 
Process analysis and sensitivity of ozone and particulate matter to precursor emissions, Atmos. Environ., 44, 3719-3727, doi:10.1016/j.atmosenv.2010.03.036, 2010.

Lou, S. J., Liao, H., and Zhu, B.: Impacts of aerosols on surfacelayer ozone concentrations in China through heterogeneous reactions and changes in photolysis rates, Atmos. Environ., 85, 123138, doi:10.1016/j.atmosenv.2013.12.004, 2014.

$\mathrm{Lu}, \mathrm{W} . \mathrm{Z}$. and Wang, X. K.: Evolving trend and selfsimilarity of ozone pollution in central Hong Kong ambient during 1984-2002, Sci. Total Environ., 357, 160-168, doi:10.1016/j.scitotenv.2005.03.015, 2006.

Ma, J. Z., Xu, X. B., Zhao, C. S., and Yan, P.: A review of atmospheric chemistry research in China: Photochemical smog, haze pollution, and gas-aerosol interactions, Adv. Atmos. Sci., 29, 1006-1026, doi:10.1007/s00376-012-1188-7, 2012.

Mlawer, E. J., Taubman, S. J., Brown, P. D., Iacono, M. J., and Clough, S. A.: Radiative transfer for inhomogeneous atmospheres: RRTM, a validated correlated-k model for the longwave, J. Geophys. Res.-Atmos., 102, 16663-16682, doi:10.1029/97jd00237, 1997.

Monin, A. S. and Obukhov, A. M.: Basic laws of turbulent mixing in the surface layer of the atmosphere, Contributions of the Geophysical Institute of the Slovak Academy of Sciences, 151, 163-187, 1954.

Peng, J. B.: An Investigation of the Formation of the Heat Wave in Southern China in Summer 2013 and the Relevant Abnormal Subtropical High Activities, Atmos. Ocean. Sci. Lett., 7, 286290, 2014.

Ran, L., Zhao, C. S., Geng, F. H., Tie, X. X., Tang, X., Peng, L., Zhou, G. Q., Yu, Q., Xu, J. M., and Guenther, A.: Ozone photochemical production in urban Shanghai, China: Analysis based on ground level observations, J. Geophys. Res.-Atmos., 114, D15301, doi:10.1029/2008jd010752, 2009.

Shao, M., Zhang, Y. H., Zeng, L. M., Tang, X. Y., Zhang, J., Zhong, L. J., and Wang, B. G.: Ground-level ozone in the Pearl River Delta and the roles of VOC and $\mathrm{NO}_{x}$ in its production, J. Environ. Manage., 90, 512-518, doi:10.1016/j.jenvman.2007.12.008, 2009.

Shi, C. Z., Wang, S. S., Liu, R., Zhou, R., Li, D. H., Wang, W. X., Li, Z. Q., Cheng, T. T., and Zhou, B.: A study of aerosol optical properties during ozone pollution episodes in 2013 over Shanghai, China, Atmos. Res., 153, 235-249, doi:10.1016/j.atmosres.2014.09.002, 2015.

Sillman, S.: The relation between ozone, $\mathrm{NO}_{x}$ and hydrocarbons in urban and polluted rural environments, Atmos. Environ., 33, 1821-1845, doi:10.1016/S1352-2310(98)00345-8, 1999.

State Environmental Protection Administration of China: China National Environmental Protection Standard: Automated Methods for Ambient Air Quality Monitoring, China Environmental Science Press, Beijing, 2006.

Tang, G., Li, X., Wang, Y., Xin, J., and Ren, X.: Surface ozone trend details and interpretations in Beijing, 2001-2006, Atmos. Chem. Phys., 9, 8813-8823, doi:10.5194/acp-9-8813-2009, 2009.

Tang, W. Y., Zhao, C. S., Geng, F. H., Peng, L., Zhou, G. Q., Gao, W., Xu, J. M., and Tie, X. X.: Study of ozone "weekend effect" in Shanghai, Sci. China Ser. D, 51, 1354-1360, doi:10.1007/s11430-008-0088-2, 2008.

Tu, J., Xia, Z. G., Wang, H. S., and Li, W. Q.: Temporal variations in surface ozone and its precursors and meteorological effects at an urban site in China, Atmos. Res., 85, 310-337, doi:10.1016/j.atmosres.2007.02.003, 2007.

Wang, H. L., Chen, C. H., Wang, Q., Huang, C., Su, L. Y., Huang, H. Y., Lou, S. R., Zhou, M., Li, L., and Qiao, L. P.: Chemical loss of volatile organic compounds and its impact on the source analysis through a two-year continuous measurement, Atmos. Environ., 80, 488-498, 2013.

Wang, H. X., Zhou, L. J., and Tang, X. Y.: Ozone concentrations in rural regions of the Yangtze Delta in China, J. Atmos. Chem., 54, 255-265, doi:10.1007/s10874-006-9024-z, 2006.

Wang, T., Wei, X. L., Ding, A. J., Poon, C. N., Lam, K. S., Li, Y. S., Chan, L. Y., and Anson, M.: Increasing surface ozone concentrations in the background atmosphere of Southern China, 19942007, Atmos. Chem. Phys., 9, 6217-6227, doi:10.5194/acp-96217-2009, 2009.

Wang, T. J., Lam, K. S., Xie, M., Wang, X. M., Carmichael, G., and Li, Y. S.: Integrated studies of a photochemical smog episode in Hong Kong and regional transport in the Pearl River Delta of China, Tellus B, 58, 31-40, doi:10.1111/j.16000889.2005.00172.x, 2006.

Wang, X. M., Lin, W. S., Yang, L. M., Deng, R. R., and Lin, H.: A numerical study of influences of urban land-use change on ozone distribution over the Pearl River Delta region, China, Tellus B, 59, 633-641, doi:10.1111/j.1600-0889.2007.00271.x, 2007.

Wang, X. M., Chen, F., Wu, Z. Y., Zhang, M. G., Tewari, M., Guenther, A., and Wiedinmyer, C.: Impacts of Weather Conditions Modified by Urban Expansion on Surface Ozone: Comparison between the Pearl River Delta and Yangtze River Delta Regions, Adv. Atmos. Sci., 26, 962-972, doi:10.1007/s00376-009-80012, 2009.

Wei, X. L., Liu, Q., Lam, K. S., and Wang, T. J.: Impact of precursor levels and global warming on peak ozone concentration in the Pearl River Delta Region of China, Adv. Atmos. Sci., 29, 635645, doi:10.1007/s00376-011-1167-4, 2012.

Xie, M., Wang, T. J., Jiang, F., and Yang, X. Q.: Modeling of natural $\mathrm{NO}_{x}$ and $\mathrm{VOC}$ emissions and their effects on tropospheric photochemistry in China, Environ. Sci. China, 28, 31-40, 2007.

Xie, M., Li, S., Jiang, F., and Wang, T. J.: Methane emissions from terrestrial plants over China and their effects on methane concentrations in lower troposphere, Chinese Sci. Bull., 54, 304-310, doi:10.1007/s11434-008-0402-6, 2009.

Xie, M., Zhu, K. G., Wang, T. J., Yang, H. M., Zhuang, B. L., Li, S., Li, M. G., Zhu, X. S., and Ouyang, Y.: Application of photochemical indicators to evaluate ozone nonlinear chemistry and pollution control countermeasure in China, Atmos. Environ., 99, 466-473, doi:10.1016/j.atmosenv.2014.10.013, 2014.

Xie, M., Liao, J., Wang, T., Zhu, K., Zhuang, B., Han, Y., Li, M., and $\mathrm{Li}, \mathrm{S}$.: Modeling of the anthropogenic heat flux and its effect on regional meteorology and air quality over the Yangtze River Delta region, China, Atmos. Chem. Phys., 16, 6071-6089, doi:10.5194/acp-16-6071-2016, 2016a.

Xie, M., Zhu, K. G., Wang, T. J., Chen, P. L., Han, Y., Li, S., Zhuang, B. L., and Shu, L.: Temporal characterization and regional contribution to $\mathrm{O}_{3}$ and $\mathrm{NO}_{x}$ at an urban and a suburban site in Nanjing, China, Sci. Total Environ., 551, 533-545, doi:10.1016/j.scitotenv.2016.02.047, 2016b.

Yarwood, G., Rao, S., Yocke, M., and Whitten G.: Updates to the Carbon Bond chemical mechanism: CB05, Final Report to the US EPA, RT-0400675, 2005. 
Zhang, Q., Streets, D. G., Carmichael, G. R., He, K. B., Huo, H., Kannari, A., Klimont, Z., Park, I. S., Reddy, S., Fu, J. S., Chen, D., Duan, L., Lei, Y., Wang, L. T., and Yao, Z. L.: Asian emissions in 2006 for the NASA INTEX-B mission, Atmos. Chem. Phys., 9, 5131-5153, doi:10.5194/acp-9-5131-2009, 2009.

Zhang, X. Y., Zhang, P., Zhang, Y., Li, X. J., and Qiu, H.: The trend, seasonal cycle, and sources of tropospheric $\mathrm{NO}_{2}$ over China during 1997-2006 based on satellite measurement, Sci. China Ser. D, 50, 1877-1884, doi:10.1007/s11430-007-0141-6, 2007.

Zhang, Y. H., Su, H., Zhong, L. J., Cheng, Y. F., Zeng, L. M., Wang, X. S., Xiang, Y. R., Wang, J. L., Gao, D. F., Shao, M., Fan, S. J., and Liu, S. C.: Regional ozone pollution and observation-based approach for analyzing ozone-precursor relationship during the PRIDE-PRD2004 campaign, Atmos. Environ., 42, 6203-6218, doi:10.1016/j.atmosenv.2008.05.002, 2008.
Zhu, B., Kang, H. Q., Zhu, T., Su, J. F., Hou, X. W., and Gao, J. H.: Impact of Shanghai urban land surface forcing on downstream city ozone chemistry, J. Geophys. Res.-Atmos., 120, 4340-4351, doi:10.1002/2014JD022859, 2015. 